\title{
A model for the sustainable selection of building envelope assemblies
}

\author{
Patricia Huedo ${ }^{1}$, Dr in Architecture, Universitat Jaume I, huedo@ uji.es \\ Elena Mulet, Dr in Industrial Engineering, Universitat Jaume I, emulet@ uji.es \\ Belinda López-Mesa , Dr in Architecture, Universidad de Zaragoza, belinda@unizar.es
}

\begin{abstract}
The aim of this article is to define an evaluation model for the environmental impacts of building envelopes to support planners in the early phases of materials selection. The model is intended to estimate environmental impacts for different combinations of building envelope assemblies based on scientifically recognised sustainability indicators. These indicators will increase the amount of information that existing catalogues show to support planners in the selection of building assemblies.

To define the model, first the environmental indicators were selected based on the specific aims of the intended sustainability assessment. Then, a simplified LCA methodology was developed to estimate the impacts applicable to three types of dwellings considering different envelope assemblies, building orientations and climate zones. This methodology takes into account the manufacturing, installation, maintenance and use phases of the building. Finally, the model was validated and a matrix in Excel was created as implementation of the model.
\end{abstract}

\section{Keywords}

Buildings sustainability. Sustainability indicators. Envelope assemblies.

\section{Introduction}

Construction is responsible for an indiscriminate use of non-renewable resources and is an important source of waste and pollution for the air, soil and water. According to UNEP (United Nations Environment Programme) and OECD (Organisation for Economic Cooperation and Development) data, the built-up environment accounts for between $25 \%$ and $40 \%$ of energy consumption, between $30 \%$ and $40 \%$ of the solid waste burden, and between $30 \%$ and $40 \%$ of the greenhouse gas emissions generated worldwide [1]. It is important to stress the importance of studying the potential environmental impacts produced by the use of certain building materials, but it is also important to highlight the impact represented by the combination of these materials when used in a certain constructive assembly [2]. Likewise, it is necessary to be able to establish relationships between these impacts and those produced throughout the lifespan of the building, due to both the actual materials used and the energy consumption linked to the building assemblies employed in the building envelope. As the person responsible for developing the core of the building around which the rest will later be constructed, the designer or planner must be able to control the selection of suitable materials and building assemblies used in their project [3]. In order to make their decisions they therefore need to have access not only to valid technological alternatives but also to relevant objective information about them, as well as instruments that allow them to be evaluated in a comprehensive manner [4].

$1 *$ Corresponding author: Patricia Huedo. Department of Mechanical Engineering and Construction. Universitat Jaume I, Castellón de la Plana, Spain

Tel: +34964729163

Fax: +34964728106

huedo@uji.es 
Thus, to increase the sustainability of construction it is necessary to consider reducing both the energy consumption and the $\mathrm{CO}_{2}$ emissions of buildings by improving the building assemblies that make up the building envelope. This envelope has to guarantee the quality of the environment inside the building, since the exchange between the inner and outer environment takes place through it. It is also the point where illumination, ventilation or heat flow act as fundamental design parameters [5].

Obviously the environmental assessment of the building assemblies used for the envelope requires a scientifically rigorous methodology. Among the leading methodologies accepted by the scientific community for environmental impact assessment, the Life Cycle Analysis (LCA) is the most suitable because it is an analytical procedure focused on evaluating the whole life cycle. LCA, however, is an exhaustive, very laborious and complex process that must be carried out by highly skilled professionals and the time needed to apply it is often incompatible with the time available for producing designs. As a result, few life cycle analyses of buildings have been carried out in some countries. In the international context, a wide variety of tools based on the LCA methodology have been developed with the specific aim of aiding the planner in the sustainable selection of building assemblies. These tools allow the components of the building to be evaluated and cover all the different phases of the life cycle [6], [7]. These tools hardly apply outside the countries where they were developed since the environmental impact level caused by building materials and assemblies varies from one territory to another, due to the geographic placement of raw materials extraction and transformation plants in relation to the building location as well as to the possible differences in construction techniques [8].

In Spain, there are environmental assessment tools such as TCQ2000 and its module TCQGMA, which only assess the impacts generated during the manufacturing process and installation of the materials, i.e. the embodied impacts, without taking into account the use phase of the building, i.e. the operating impacts. On the other hand, there are building energy simulation tools such as LIDER and CALENER which offer data about consumption and $\mathrm{CO}_{2}$ emissions of buildings [7], [9], [10]; they do not, however, take into account the embodied impacts of the manufacturing and installation stages or the impacts generated by the maintenance of the building.

At an international context, there are several studies that propose different methods to evaluate the environmental impact of buildings which consider both embodied and operating energy ([11], [12], [13], [14], [15], [16]). One of them deserves special mention because it synthetises all collected data in the form of indicators to assign scores to each design alternative, considering the different impacts along the whole building life cycle, which is of application to New Zealand houses [11]. The evaluation in this model is made for the whole building, whereas in this paper we focus on the building envelope in order to support the early phases of building envelope materials selection. Our aim is to increase the amount of information that existing catalogues show to support planners in the selection of building assemblies.

Scoring by means of indicators allows to compare data about different buildings using a reference to which the inputs and outputs can be related, the functional unit. It also allows to check the fulfilment of environmental prerequisites, in the initial phases of design, even before the actual design starts.

It would therefore be very interesting to have an evaluation model based on environmental indicators that assigns buildings envelope impact scores in a simple way, considering the whole life cycle. This model that would specifically be developed for building envelopes, would not only evaluate the embodied impacts of the manufacturing, installation and maintenance stages, but would also take into account the impacts generated by the installations due to the contribution of the envelope to energy efficiency during the use phase of the building (operating impacts). The interest in linking both types of impact stems from the fact that certain building assemblies might not substantially improve the energy efficiency of the building or that some high energy efficiency building assemblies include materials with a high impact in their manufacturing process, installation or maintenance. Planners require both embodied and operating energyrelated information about building envelope solutions in order to select the building assemblies that ensure good environmental behaviour of the building throughout the whole of its life cycle.

An indicator is an environmental variable or estimation that provides aggregated summarised information about a phenomenon [17]. Its function is therefore to provide information both clearly and efficiently. It is necessary to establish a minimum essential content for presenting indicators, both for processes involving the selection of the indicators themselves and for the analysis and validation of the information they contain, with the aim of having access to specific concise information so as to avoid ambiguities that may arise during their interpretation, as well as to be able to take them as the basis on which to make correct decisions. The system used to obtain the values that allow the development of the formulas for the indicators would be based on a simplified LCA methodology. 


\section{Aim}

The main aim of this article is to define a model for assessing the environmental impact, based on a simplified Life Cycle Analysis (LCA) methodology, produced by different building assemblies used in the envelope of buildings so that they can be assigned a score by means of known sustainability indicators that take into account the manufacturing, installation, use and maintenance phases of building construction.

With this assessment model the intention is to contribute to the development of a tool, to be applied in Spain in the early phases of building materials selection, that allows to obtain estimated live data about the embodied and operating environmental impacts of building envelope assemblies, to aid the design planner in the selection of solutions of low environmental impact before the actual design starts. The main contribution of the model is proposing a method to estimate how to score the envelope impacts at an earlier phase than the existing methods in a simple way.

\section{Research methodology}

The methodology that was followed to develop this model is summarised in the diagram below (Figure 1).

Selection of indicators to be developed and obtaining the values of the impact

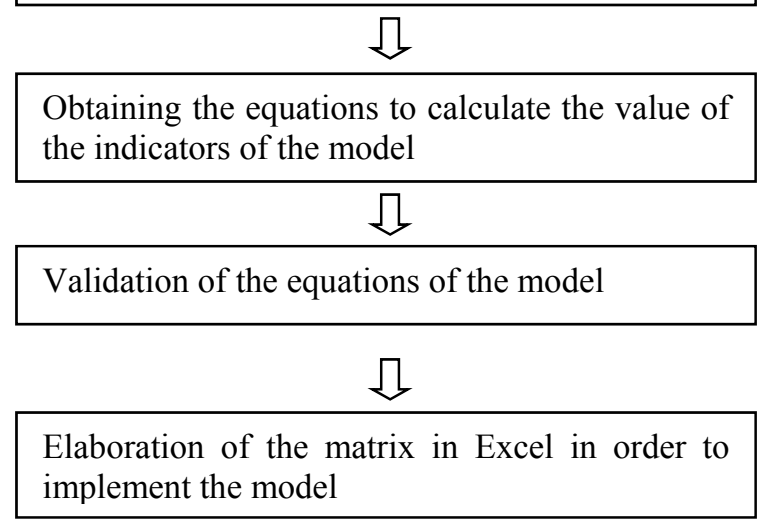

Figure 1 Methodological overview of the research

The adopted methodology is based on the generation of data regarding materials and assemblies of regular use in building construction in Spain, required to develop mathematical equations for a set of sustainability indicators previously selected for each of the building life cycle phases.

\subsection{Selection of indicators and impacts rating}

From a methodological point of view it must be underlined that the framework of analysis chosen to structure the system of indicators is the so-called "Pressure-State-Response (PSR)", adopted by the OECD [18] and based on a causality model.

According to the general principles established in the norm ISO 15392, when evaluating buildings sustainability, the three dimensions of the sustainable development (environmental, social and economic) should be considered. However, this norm also establishes that the evaluation of sustainability can also be undertaken separately, depending on the scope of the evaluation. This work focuses on the environmental and economic evaluation of buildings envelope.

As the number of indicators that can be proposed is quite large, before going on it is necessary to select certain indicators, to clearly establish the sustainability goals and to determine what selection criteria are to be used. Hence, the grouping proposed by Standard UNE EN 15643-2 was considered, in the following areas:

- Indicators that describe environmental emissions,

- Indicators that describe use of resources,

- Indicators that provide complementary environmental information about waste.

The economic performance assessment according to Norm EN 15643-4 was additionally taken into consideration.

To select the indicators, several studies were analysed ([19], [20], [21], [22], [23]), the conclusions being that:

- As far as emissions are concerned, all the agents involved agree on considering global warming potential or equivalent $\mathrm{CO}_{2}$ emissions and their direct association with the emissions of other gases (sulphur oxides 
(SOx), nitrogen oxides (NOx), methane (CH4), etc.) as the most representative indicator when it comes to evaluating the environmental quality of buildings, as can be deduced from the EMEP/CORINAIR 2007 methodology drawn up by the EEA [24].

- As regards the indicators that describe consumption of resources, in accordance with the recommendations established in Directive 2012/27/EU, the primary energy consumption indicator was selected to evaluate the energy behaviour of the building. Likewise, a drinking water consumption indicator was selected due to the water stress in Spain.

- With regard to waste, both a hazardous waste indicator and a non-hazardous waste indicator were incorporated that will affect the manufacturing and installation phase, the aim being to give priority to the use of materials that do not generate hazardous waste during their manufacturing process [25], [26].

- Regarding cost appraisal, several economic indicators were selected to provide information about investment costs and energy costs in the manufacturing and installation as well as the maintenance and use phases.

The set of indicators of the impact to be evaluated, for each of the phases of the life cycle, are shown in Table 1, where the units of each indicator are specified.

The value of the selected impacts is obtained by applying a simplified LCA methodology following the diagram set out in Figure 2, the general aim being to quantify the environmental impact of a single home throughout its lifespan [27].

Table 1 Indicators for the impact to be evaluated and the phases of the life cycle

\begin{tabular}{|c|c|c|c|c|c|}
\hline & Indicators that describe environmental impacts & Units & Manufacturing ph. & Maintenance ph. & Use phase \\
\hline \multirow[t]{2}{*}{1} & Global Warming Potential & kg.Eq.CO $\mathrm{CO}_{2} / \mathrm{m}^{2}$ & $\mathrm{x}$ & $\mathrm{x}$ & $x$ \\
\hline & Indicators that describe use of resources & Units & Manufacturing ph. & Maintenance ph. & Use phase \\
\hline 2 & Primary energy consumption & $\mathrm{Mj}, \mathrm{kWh} / \mathrm{m}^{2}$ & $x$ & $\mathrm{x}$ & $\mathrm{x}$ \\
\hline \multirow[t]{2}{*}{3} & Water consumption & $1 / \mathrm{m}^{2}$ & $x$ & $\mathrm{x}$ & \\
\hline & $\begin{array}{l}\text { Indicators that describe complementary } \\
\text { environmental information }\end{array}$ & Units & Manufacturing ph. & Maintenance ph. & Use phase \\
\hline \multirow{3}{*}{4} & Non-hazardous waste & $\mathrm{Kg} / \mathrm{m}^{2}$ & $x$ & & \\
\hline & Hazardous waste & $\mathrm{Kg} / \mathrm{m}^{2}$ & $x$ & & \\
\hline & Economic indicators & Units & Manufacturing ph. & Maintenance ph. & Use phase \\
\hline \multirow{3}{*}{5} & Investment costs & $€ / \mathrm{m}^{2}$ & $\mathrm{x}$ & & \\
\hline & Maintenance costs & $€ / \mathrm{m}^{2}$ & & $\mathrm{x}$ & \\
\hline & Energy costs & $€ / \mathrm{m}^{2}$ & $\mathrm{x}$ & $\mathrm{x}$ & $\mathrm{x}$ \\
\hline
\end{tabular}

\subsection{The simplified LCA methodology applied to obtain impact values}




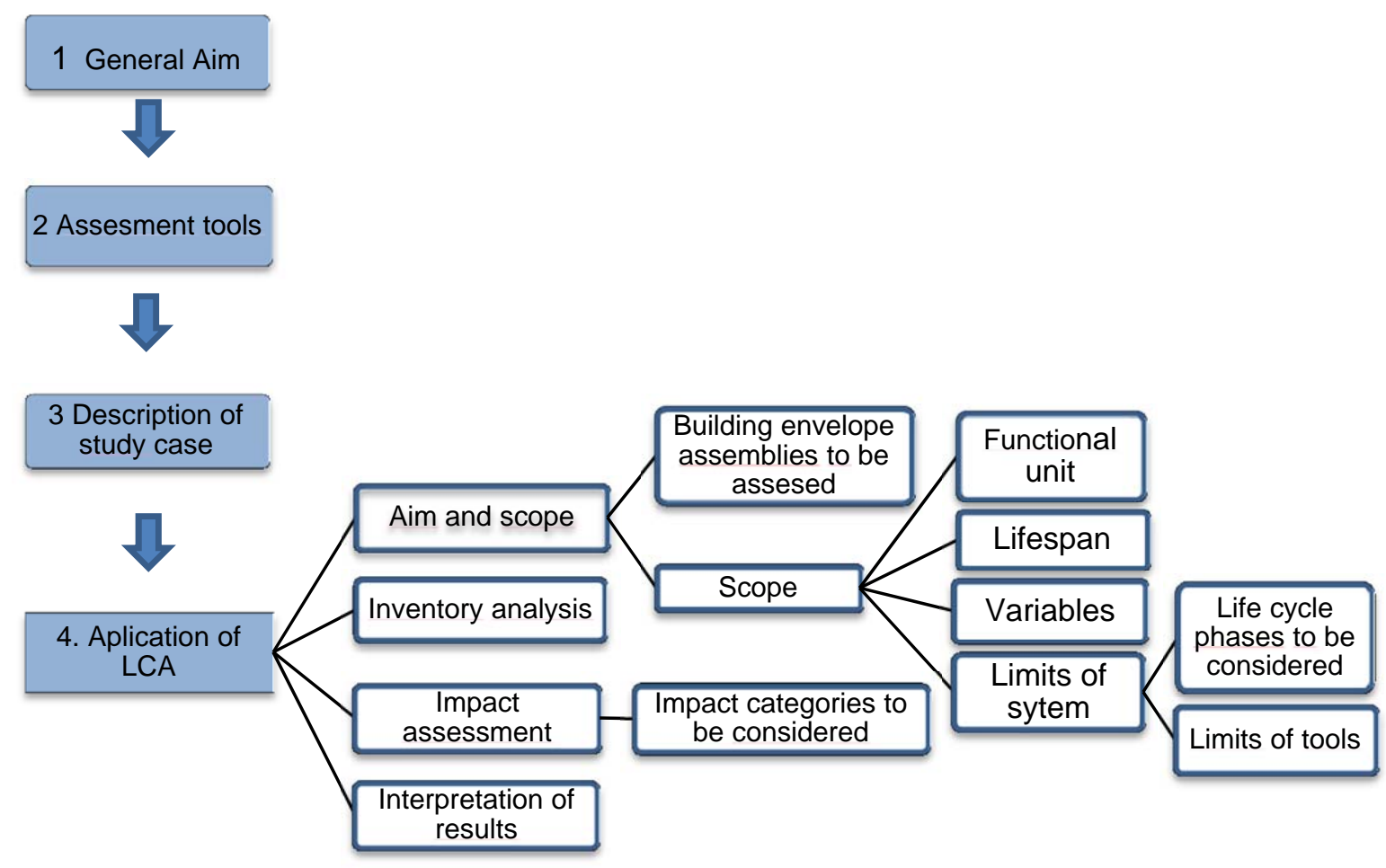

Figure 2 Diagram showing the simplified LCA methodology applied to obtain impact values

The following steps were observed in the application of the LCA methodology:

- First, the impacts during the manufacturing process and installation of the building materials were calculated using the software application TCQ2000 as well as its environmental management module TCQGMA [28]. This tool defines the type and amount of materials used for each element by associating the input data and the existing values in the BEDEC database [29] referring to the impacts (energy consumption, $\mathrm{CO}_{2}$ emissions, hazardous and non-hazardous waste generated during the manufacturing and installation phase). Water consumption appears as another item in the breakdown of materials that make up each building assembly.

- Second, the potential impacts produced by the different building assemblies during the building corrective maintenance were estimated. The TCQ2000 software, however, does not incorporate data about maintenance by default, which meant that they had to be obtained by assigning each of the materials that make up the building assembly a reconditioning factor, $F_{R}$, to reflect the number of times that material will have to be replaced throughout the lifespan of the building [30]. The impact value is obtained by multiplying the impacts generated by each material by the corresponding $F_{R}$. The durability of each element within the building assemblies that were analysed was established by following the recommendations set out in Standard ISO 15686-1.

The durability values used for each of the materials composing each building assembly were defined through the review of relevant sources and databases [31], [32]. These sources provided sufficient information regarding the position of the component in the building assembly. For example, the waterproof sheet durability is different in a conventional and an inverted roof since in the latter the insulating material protects the waterproof sheet from temperature changes. Additionally, to these considerations we also took into account the fact than when certain components need replacement, other components could also be affected. It is the case, for example, of the geotextile and mortar above the waterproof sheet that will have to be substituted if the waterproof is replaced (Table 2).

The assessment of the impacts due to building materials renovation was undertaken using the module TCQGMA of the TCQ2000 software, multiplying the generated impact of each constituting material by the reconditioning factor $\mathrm{F}_{\mathrm{R}}$ minus 1 (to deduct the impact of the manufacturing and installation phase).

Table 2 shows, as an example, the data regarding a conventional, non-ventilated, trafficable flat roof and its constituting materials for the maintenance phase inventory. In the first row the code assigned to each construction assembly is shown (C1) as well as the designation of such building assembly. In the first five 
columns the constituting materials of each assembly, their thickness, durability and reconditioning factor are given; in the next three columns the impacts during the corrective maintenance phase (considering the whole building lifespan) are shown.

Table 2. Impacts due to the roof materials, during the maintenance phase.

\begin{tabular}{|c|c|c|c|c|c|c|c|}
\hline \multirow[t]{2}{*}{ C1 } & \multicolumn{4}{|c|}{ C1 Flat roof, conventional, non-ventilated, trafficable } & \multicolumn{3}{|c|}{ MAINTENANCE PHASE } \\
\hline & Material & $\begin{array}{c}\text { Thickness } \\
\mathrm{m}\end{array}$ & $\begin{array}{c}\text { Durability } \\
\text { years }\end{array}$ & $F_{R}$ & $\begin{array}{c}\text { Emissions } \\
{ }^{*}\left(\mathrm{~F}_{\mathrm{R}}-1\right) \\
\mathrm{kg} \mathrm{CO}\end{array}$ & \begin{tabular}{|c|}
$\begin{array}{c}\text { Energy } \\
\text { consumtion } \\
*\left(\mathrm{~F}_{\mathrm{R}}-1\right) \\
\mathrm{kWh} / \mathrm{m}^{2}\end{array}$ \\
\end{tabular} & $\begin{array}{c}\text { Investment } \\
\text { costs * }\left(F_{R^{-}}\right. \\
1) € / \mathrm{m}^{2}\end{array}$ \\
\hline & $\mathrm{P} \_$Finishing ceramic tiles & 0.010 & 50 & 1.00 & 0.00 & 0.00 & 0.00 \\
\hline & MA_ Mortar & 0.040 & 37 & 3.66 & 13.83 & 25.30 & 18.38 \\
\hline 3 & Csa_Geotextile from polypropylene $125 \mathrm{gr} / \mathrm{m} 2$ & 0.00013 & 30 & 3.66 & 4.44 & 8.41 & 5.69 \\
\hline & I_Waterproof sheet bitumen LO-40/FV & 0.007 & 13.67 & 3.66 & 88.13 & 164.67 & 88.02 \\
\hline & Cs_Geotextile from polypropylene $125 \mathrm{gr} / \mathrm{m} 2$ & 0.00013 & 30 & 1.67 & 1.09 & 2.10 & 1.43 \\
\hline & AT_ Thermal insulation of XPS & 0.050 & 50 & 1.00 & 0.00 & 0.00 & 0.00 \\
\hline & B_Vapour barrier & 0.005 & 61 & 0.82 & 0.00 & 0.00 & 0.00 \\
\hline $8+1$ & FP_Aerated concrete for roof slope & 0.048 & 50 & 1.00 & 0.00 & 0.00 & 0.00 \\
\hline $9 \mathrm{~s}$ & SR_Reinforced concrete one-way slab, ceramic hollow plot & 0.300 & 50 & 1.00 & 0.00 & 0.00 & 0.00 \\
\hline $10 \mathrm{~F}$ & RI_Plastering & 0.010 & 46 & 1.09 & 0.15 & 0.46 & 0.42 \\
\hline & Total & 0.470 & & & 107.64 & 200.93 & 113.94 \\
\hline
\end{tabular}

Finally, consumptions and $\mathrm{CO}_{2}$ emissions, resulting from heating and air conditioning systems during the use phase, are calculated using the energy simulation tools LIDER [33] and CALENER VYP [34]. The latter is an official tool for energy certification of buildings in Spain, which is only applicable to residential buildings. For this reason the results being showed in this paper are only valid for residential buildings. The CALENER VYP tool is used here to determine the heating and cooling energy demands, the final and primary energy consumptions, and the $\mathrm{CO}_{2}$ emissions of the building under study during the use phase.

Table 3 shows the building assemblies that are most commonly employed for the building envelope and which were chosen for this study. Each construction assembly is designated with a capital letter that indicates the class $(\mathrm{C}=$ roof, $\mathrm{F}=$ façade and $\mathrm{H}=$ carpentry $)$ and their numerical index that indicates the type of building assembly.

Combining the different building assemblies with one another results in 45 combinations for the envelope that are designated by means of the three letters with their corresponding indices. Calculations for the use phase are carried out for the 45 combinations of the building envelope.

For this study, in order to obtain comparable results, two different climate zones, B3 and E1, were selected. A climate zone is composed by the places of a territory where outdoor conditions are considered to result in common thermal loads for buildings energy demand. In the Spanish Building Code (Código Técnico de la Edificación, CTE) in its document DB-HE 1 [35], each climate zone of the Spanish Peninsula is identified by a letter that defines the winter severity (from A to E, being $\mathrm{E}$ the most severe), and by a number for the summer severity (from 1 to 4 , being 4 the most severe). Climate zone B3 constitutes a temperate humid climate covering approximately the entire Mediterranean basin and climate zone E1 constitutes a cold dry climate which extends inside the Peninsula.

Likewise, calculations were performed in two building orientations (North-easterly orientation - NE - and South-easterly orientation - SE). Altogether 45 combinations were evaluated in two orientations and two climate zones, that is to say a total of 180 options. All the values were obtained for the particular case of a two-storey semi-detached house with a floor area of $93.5 \mathrm{~m}^{2}$, the functional unit being taken as $1 \mathrm{~m}^{2}$ of net floor area and a service life of 50 years.

Table 3. Identification of the most commonly used building envelope assemblies 

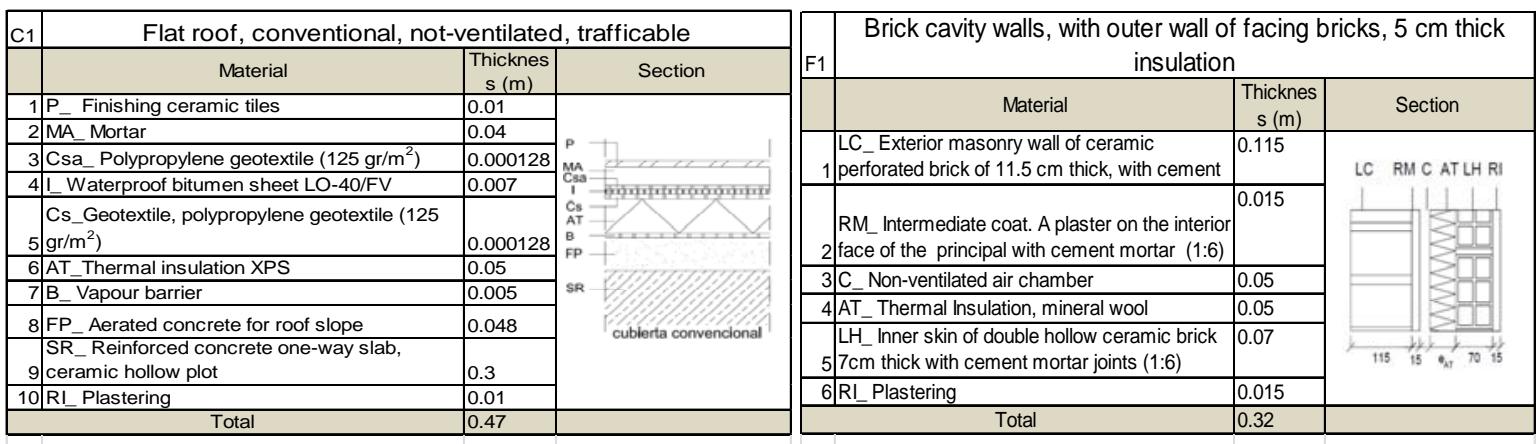

\begin{tabular}{|c|c|c|c|}
\hline \multirow[t]{2}{*}{$\mathrm{C} 2$} & \multicolumn{3}{|c|}{ Flat roof ventilated, trafficable } \\
\hline & Material & \begin{tabular}{|c|} 
Thicknes \\
$\mathrm{s}(\mathrm{m})$
\end{tabular} & Section \\
\hline & $\mathrm{P}_{-}$Finishing ceramic tiles & 0.01 & \multirow{4}{*}{ 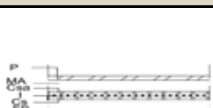 } \\
\hline & MA_Mortar & 0.04 & \\
\hline & Csa_Geotextile, polypropylene $125 \mathrm{gr} / \mathrm{m}^{2}$ & 0.000128 & \\
\hline & I Double waterproof sheet bitumen LO-40/FV & 0.007 & \\
\hline & Cs_Geotextile, polypropylene $125 \mathrm{gr} / \mathrm{m}^{2}$ & 0.000128 & \\
\hline & FP_Ceramic tiles for roof slope & 0.35 & \\
\hline & C_ Ventilated air chamber & 0.003 & \\
\hline & AT_Thermal Insulation of mineral wool & 0.005 & \\
\hline & $\begin{array}{l}\text { unidirectional fabric forging with ceramic } \\
\text { elements }\end{array}$ & 0.3 & \\
\hline & RI_Plastering & 0.01 & \\
\hline & Total & 0.725 & \\
\hline
\end{tabular}

\begin{tabular}{|l}
\hline Brick cavity walls, with coated outer wall of brickwork, $5 \mathrm{~cm}$ thick \\
\hline
\end{tabular}

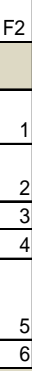

\begin{tabular}{|c|c|c|}
\hline \multicolumn{3}{|c|}{ insulation } \\
\hline Material & $\begin{array}{c}\text { Thicknes } \\
\mathrm{s}(\mathrm{m})\end{array}$ & Section \\
\hline $\begin{array}{l}\mathrm{RE}_{1} \begin{array}{l}\mathrm{R} \text { Continuous outer coating with cement } \\
\text { mortar (1:6) }\end{array} \\
.\end{array}$ & 0.015 & RE LC CAT LH RI \\
\hline $\begin{array}{l}\text { LC_Exterior masonry wall of perforated } 12 \mathrm{~cm} \\
\text { thick ceramic brick, with cement mortar joints }\end{array}$ & 0.115 & $\left.\stackrel{1}{\prime \prime}\right|^{\prime}$ \\
\hline 3 C_Non-ventilated air chamber & 0.05 & ब्रण \\
\hline 4 AT__Thermal Insulation, mineral wool & 0.05 & \$प्त \\
\hline \begin{tabular}{l|l}
5 & LH_ Inner layer of double hollow ceramic brick \\
$7 \mathrm{~cm}$ thick with cement mortar joints (1:6)
\end{tabular} & 0.07 & 4270 is \\
\hline 6|RI_Plastering & 0.015 & \\
\hline Total & 0.32 & \\
\hline
\end{tabular}

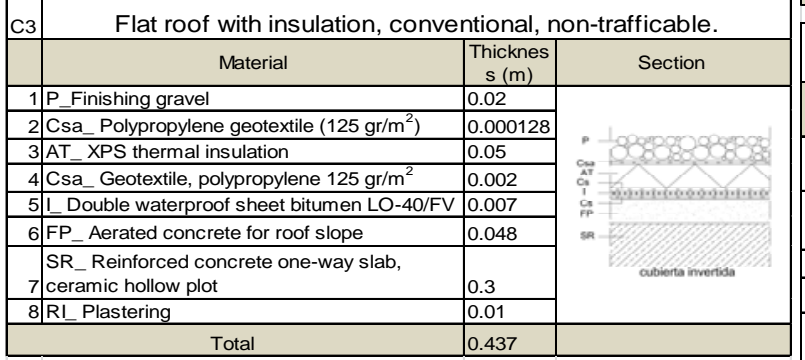

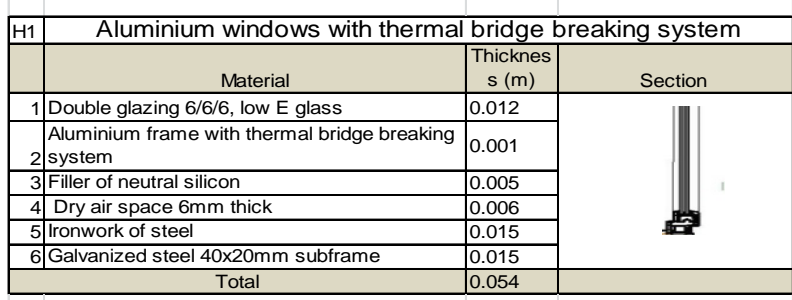

\begin{tabular}{|c|c|c|c|}
\hline \multirow[t]{2}{*}{$\mathrm{H} 2$} & \multicolumn{3}{|c|}{ PVC windows with thermal bridge breakage } \\
\hline & Material & \begin{tabular}{|c|} 
Thicknes \\
$\mathrm{s}(\mathrm{m})$
\end{tabular} & Section \\
\hline & Double glazing $6 / 6 / 6$, low $E$ glass & 0.012 & \\
\hline & PVC frame with three chambers & 0.001 & \\
\hline & Filler of neutral silicon & 0.005 & \\
\hline & Dry air space $6 \mathrm{~mm}$ thick & 0.006 & \\
\hline & Ironwork of steel & 0.015 & \\
\hline & Galvanized steel $40 \times 20 \mathrm{~mm}$ subframe & 0.015 & \\
\hline & Total & 0.054 & \\
\hline
\end{tabular}

\begin{tabular}{|c|c|c|c|}
\hline & \multicolumn{3}{|c|}{$\begin{array}{l}\text { Brick cavity walls, with coated outer wall of brickwork, } 10 \mathrm{~cm} \\
\text { thick insulation }\end{array}$} \\
\hline & Material & $\begin{array}{l}\text { Thicknes } \\
\mathrm{s}(\mathrm{m})\end{array}$ & Section \\
\hline & $\begin{array}{l}\text { RE_Continuous outer coating with cement } \\
\text { mortar }(1: 6)\end{array}$ & 0.015 & \multirow{2}{*}{ RE LC CAT LH R } \\
\hline & $\begin{array}{l}\text { ceramic brick } 11.5 \mathrm{~cm} \text { thick with cement } \\
\text { mortar joints (1:6) }\end{array}$ & 0.115 & \\
\hline & C_Non-ventilated air chamber & 0.05 & \\
\hline & AAT_Thermal Insulation, mineral wool & 0.1 & \\
\hline & $\begin{array}{l}\text { LH_Inner layer of double hollow ceramic brick } \\
7 \mathrm{~cm} \text { thick with cement mortar joints }(1: 6)\end{array}$ & 0.07 & \multirow[t]{2}{*}{ 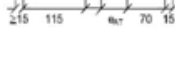 } \\
\hline & RI_Plastering & 0.015 & \\
\hline & Total & 0.37 & \\
\hline
\end{tabular}

\begin{tabular}{|c|c|c|c|c|}
\hline $\mathrm{H} 3$ & \multicolumn{4}{|c|}{ Wood windows } \\
\hline & Material & \begin{tabular}{|c|} 
Thicknes \\
$\mathrm{s}(\mathrm{m})$
\end{tabular} & Section & \\
\hline & Double glazing $6 / 6 / 6$, low $E$ glass & 0.012 & & \\
\hline & High density wood frame & 0.019 & & \\
\hline & Filler of neutral silicon & 0.005 & & \\
\hline & Dry air space $6 \mathrm{~mm}$ thick & 0.006 & & 1 \\
\hline & Ironwork of steel & 0.015 & & \\
\hline & Wood frame $40 \times 20 \mathrm{~mm}$ & 0.015 & 照 & \\
\hline & Total & 0.072 & & \\
\hline
\end{tabular}

\begin{tabular}{|c|c|c|c|}
\hline \multirow[t]{2}{*}{ F4 } & \multicolumn{3}{|c|}{ Back-ventilated façade of brickwork, $5 \mathrm{~cm}$ thick insulation } \\
\hline & Material & $\begin{array}{c}\text { Thicknes } \\
\mathrm{s}(\mathrm{m})\end{array}$ & Section \\
\hline & $\begin{array}{l}\text { RE_Outer discontinuous coating of ceramic } \\
\text { tiles mechanically fastened with aluminium } \\
\text { substructure type T }\end{array}$ & 0.02 & \multirow{6}{*}{ REC AT LC RI } \\
\hline 2 & C_Ventilated air chamber & 0.05 & \\
\hline & AT_Thermal Insulation of mineral wool & 0.05 & \\
\hline & $\begin{array}{l}\text { RM_C Continuous outer coating with cement } \\
\text { mortar }(1: 6)\end{array}$ & 0.015 & \\
\hline \multicolumn{2}{|r|}{$\begin{array}{l}\text { LC_Inner layer of double hollow ceramic brick } \\
51.5 \mathrm{~cm} \text { thick with cement mortar joints (1:6) }\end{array}$} & 0.115 & \\
\hline \multicolumn{2}{|r|}{$6 \mid \mathrm{RI}$ _Plastering } & 0.015 & \\
\hline \multicolumn{2}{|r|}{ Total } & 0.265 & \\
\hline \multirow[t]{2}{*}{ F5 } & \multicolumn{3}{|c|}{ Curtain wall } \\
\hline & Material & $\begin{array}{c}\text { Thicknes } \\
\mathrm{s}(\mathrm{m})\end{array}$ & Section \\
\hline & Double glazing $6 / 8 / 6$, low $\mathrm{E}$ glass & 0.012 & 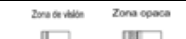 \\
\hline \multicolumn{2}{|r|}{\begin{tabular}{l|l}
2 & Aluminium substructure of tubular mullions \\
and horizontals transoms
\end{tabular}} & & \\
\hline \multicolumn{2}{|r|}{$\begin{array}{ll}3 & \text { Dry air } 8 \mathrm{~mm} \text { space } \\
\end{array}$} & 0.008 & \\
\hline \multicolumn{2}{|r|}{5 Aluminium Composite Panel } & 0.0018 & 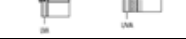 \\
\hline & Total & 0.0218 & \\
\hline
\end{tabular}

Finally, the results were used to develop the equations to calculate the indicators, as described next.

Regarding the life cycle phases, even if a LCA should cover the entire life cycle (manufacturing process and installation; use and maintenance; and demolition and final disposal) we decided to focus our research on the manufacturing and installation phase and on the use and maintenance phase, excluding the demolition and final disposal stage, as in other studies of the same nature [7], [10], [12], [13], [14], [15]. 
The reason is that the impacts due to the demolition phase are significantly low in comparison with the impacts along the whole life cycle.

\section{Obtaining the equations for calculating the indicators}

\subsection{Obtaining the equations for calculating the impacts during the manufacturing, installation and maintenance phases.}

The equations for the indicators during the manufacturing, installation and maintenance phases were obtained from the results of the potential impacts obtained by means of the TCQGMA tool, shown in Table 4. The first row indicates the phase of the life cycle under consideration and the second and third rows show the impacts that were evaluated and the corresponding units, all of which are expressed in square metres of constructed element. The column on the left contains the different building assemblies, as variables, for the different building envelope elements (roof, façade, carpentry) whose combinations were studied.

Table 4 Impacts resulting from the building assemblies: manufacturing, installation and maintenance phases

\begin{tabular}{|c|c|c|c|c|c|c|c|c|c|c|}
\hline \multicolumn{2}{|c|}{ VARIABLES } & \multicolumn{6}{|c|}{ MANUFACTURING AND INSTALLATION PHASES } & \multicolumn{3}{|c|}{ MAINTENANCE PHASE } \\
\hline & & \multirow{3}{*}{$\begin{array}{l}\text { Emissions } \\
\left(\mathrm{kg} \mathrm{CO}_{2} / \mathrm{m}^{2}\right)\end{array}$} & \multirow{3}{*}{$\begin{array}{c}\begin{array}{c}\text { Primary } \\
\text { energy } \\
\text { consump- } \\
\text { tion }\end{array} \\
\left(\mathrm{kWh} / \mathrm{m}^{2}\right)\end{array}$} & \multirow{3}{*}{$\begin{array}{c}\begin{array}{c}\text { Water } \\
\text { consump- } \\
\text { tion }\end{array} \\
\left(1 / \mathrm{m}^{2}\right)\end{array}$} & \multirow{2}{*}{\multicolumn{2}{|c|}{\begin{tabular}{|c|} 
Waste \\
Installation plus \\
packaging $\left(\mathrm{kg} / \mathrm{m}^{2}\right)$
\end{tabular}}} & \multirow{3}{*}{$\begin{array}{c}\text { Costs } \\
\text { Investment } \\
\left(€ / \mathrm{m}^{2}\right)\end{array}$} & \multirow{3}{*}{$\begin{array}{l}\text { Costs } \\
\begin{array}{r}\text { Main- } \\
\text { tenance }\end{array} \\
\left(€ / \mathrm{m}^{2}\right)\end{array}$} & \multirow{3}{*}{$\begin{array}{c}\text { Emissions } \\
\left(\mathrm{kg} \mathrm{CO}_{2} / \mathrm{m}^{2}\right)\end{array}$} & \multirow{3}{*}{$\begin{array}{c}\begin{array}{c}\text { Primary } \\
\text { energy } \\
\text { consumption }\end{array} \\
\left(\mathrm{kWh} / \mathrm{m}^{2}\right)\end{array}$} \\
\hline & & & & & & & & & & \\
\hline & & & & & \begin{tabular}{|c|} 
Hazardous \\
$\left(\mathrm{kg} / \mathrm{m}^{2}\right)$
\end{tabular} & $\begin{array}{c}\text { Non- } \\
\text { hazardous } \\
\left(\mathrm{kg} / \mathrm{m}^{2}\right) \\
\end{array}$ & & & & \\
\hline $\mathrm{C} 1$ & \multirow{3}{*}{ (1) } & 243.40 & 543.40 & 48.00 & 0.27 & 12.25 & 151.52 & 93.72 & 92.31 & 172.68 \\
\hline $\mathrm{C} 2$ & & 177.62 & 472.42 & 16.00 & 0.12 & 16.12 & 143.09 & 93.72 & 92.31 & 172.68 \\
\hline C3 & & 188.25 & 418.84 & 48.00 & 0.10 & 10.32 & 107.32 & 67.24 & 66.08 & 130.51 \\
\hline \multirow{5}{*}{\multicolumn{2}{|c|}{\begin{tabular}{l|} 
\\
$=2$ \\
$=3$ \\
$=4$ \\
$=5$ \\
\end{tabular}}} & 67.20 & 218.19 & 30.00 & 0.00 & 22.92 & 98.24 & 22.66 & 7.39 & 14.09 \\
\hline & & 42.28 & 134.44 & 24.00 & 0.00 & 10.28 & 76.38 & 22.66 & 7.39 & 14.09 \\
\hline & & 61.39 & 215.29 & 24.00 & 0.00 & 10.90 & 88.15 & 22.66 & 7.39 & 14.09 \\
\hline & & 52.22 & 192.62 & 16.00 & 0.00 & 11.51 & 128.07 & 11.78 & 4.15 & 13.00 \\
\hline & & 88.04 & 414.95 & 10.00 & 0.00 & 0.00 & 758.72 & 153.34 & 63.84 & 294.91 \\
\hline $\mathrm{H} 1$ & \multirow{3}{*}{$4=$} & 592.05 & $1,203.78$ & 0.00 & 0.06 & 0.00 & 231.58 & 165.24 & 67.06 & 300.99 \\
\hline $\mathrm{H} 2$ & & 324.42 & 743.75 & 0.00 & 0.06 & 0.00 & 218.94 & 165.24 & 67.06 & 300.99 \\
\hline $\mathrm{H} 3$ & & 37.46 & 169.85 & 0.00 & 0.06 & 0.00 & 247.90 & 409.43 & 71.88 & 326.93 \\
\hline
\end{tabular}

$\mathrm{F}_{\mathrm{S}}$ indicates the surface factor that represents the proportion of building assembly per $\mathrm{m}^{2}$ of net floor area of the building, as indicated in equation [1]. This datum is obtained by the planner from the building characteristics for which the envelope indicators are to be obtained.

$F_{S}=\frac{\text { construction element area }\left(\mathrm{m}^{2}\right)}{\text { net floor area of the building }\left(\mathrm{m}^{2}\right)}$

Table 5. Table of the factors obtained for each impact in the manufacturing and retrofit phases 


\begin{tabular}{|c|c|c|c|c|c|c|c|c|c|c|c|}
\hline \multicolumn{2}{|c|}{ VARIABLES } & \multirow{2}{*}{\begin{tabular}{|l}
\multicolumn{1}{c}{$\mathrm{F}_{\mathrm{S}}$} \\
$\begin{array}{l}\text { Surface } \\
\text { factor }\end{array}$
\end{tabular}} & \multicolumn{6}{|c|}{ MANUFACTURING PHASE } & \multicolumn{3}{|c|}{ MAINTENANCE PHASE } \\
\hline & & & $\begin{array}{c}\mathrm{CO}_{2} \\
\text { emissions } \\
\text { factor }\end{array}$ & $\begin{array}{l}\text { Energy } \\
\text { consump- } \\
\text { tion factor }\end{array}$ & $\begin{array}{c}\text { Water } \\
\text { consump- } \\
\text { tion factor }\end{array}$ & $\begin{array}{c}\text { Hazardous } \\
\text { waste factor }\end{array}$ & $\begin{array}{c}\text { Non- } \\
\text { hazardous } \\
\text { waste factor }\end{array}$ & $\begin{array}{l}\text { Investment } \\
\text { costs factor }\end{array}$ & $\begin{array}{c}\text { Main- } \\
\text { tenance } \\
\text { costs factor }\end{array}$ & $\begin{array}{c}\mathrm{CO}_{2} \\
\text { emissions } \\
\text { factor }\end{array}$ & $\begin{array}{l}\text { Consumption } \\
\text { factor }\end{array}$ \\
\hline \multicolumn{2}{|c|}{ Costructive element } & $F_{S, c u b}$ & $F_{C u b, \mathrm{CO}_{2}}^{f a b}$ & $F_{c u b k W h}^{f a b}$ & $F_{\text {cub agua }}^{f a b}$ & $F_{c u b \text { resp }}^{\text {fub }}$ & $F_{\text {cub rosmp }}^{f a b}$ & $F_{c u b}^{f a b} \frac{m^{2}}{c^{2}}$ & $F_{c u b}^{\text {main }}$ ef $_{m L^{2}}$ & $F_{c u b, \mathrm{CO}_{2}}^{\text {main }}$ & $F_{\text {cub kWh }}^{\text {main }}$ \\
\hline $\mathrm{C} 1$ & & \multirow{3}{*}{0.72} & 243.40 & 543.40 & 48.00 & 0.27 & 12.25 & 151.52 & 93.72 & 92.31 & 172.68 \\
\hline $\mathrm{C} 2$ & & & 177.62 & 472.42 & 16.00 & 0.12 & 16.12 & 143.09 & 93.72 & 92.31 & 172.68 \\
\hline $\mathrm{C} 3$ & & & 188.25 & 418.84 & 48.00 & 0.10 & 10.32 & 107.32 & 67.24 & 66.08 & 130.51 \\
\hline \multicolumn{2}{|c|}{ Types of façade } & $F_{S, f a c}$ & $F_{\mathrm{fac}, \mathrm{CO}_{2}}^{\mathrm{fab}}$ & $F_{\text {fac } k W h}^{f a b}$ & $F_{\text {fac agua }}^{f a b}$ & $H_{\text {fac resp }}^{f a b}$ & $F_{f a c \text { resnp }}^{f a b}$ & $F_{f a c}^{f a b} e_{/ m z}$ & $F_{f a c \in / m^{2}}^{\operatorname{man}}$ & $F_{\text {fac }}^{\operatorname{main} / m^{2}}$ & $F_{\text {fac } k W \hbar}^{\operatorname{main}}$ \\
\hline F1 & & \multirow{5}{*}{0.53} & 67.20 & 218.19 & 30.00 & 0.00 & 22.92 & 98.24 & 22.66 & 7.39 & 14.09 \\
\hline $\mathrm{F} 2$ & $\because:$ & & 42.28 & 134.44 & 24.00 & 0.00 & 10.28 & 76.38 & 22.66 & 7.39 & 14.09 \\
\hline F3 & :: & & 61.39 & 215.29 & 24.00 & 0.00 & 10.90 & 88.15 & 22.66 & 7.39 & 14.09 \\
\hline $\mathrm{F} 4$ & & & 52.22 & 192.62 & 16.00 & 0.00 & 11.51 & 128.07 & 11.78 & 4.15 & 13.00 \\
\hline F5 & & & 88.04 & 414.95 & 10.00 & 0.00 & 0.00 & 758.72 & 153.34 & 63.84 & 294.91 \\
\hline \multicolumn{2}{|c|}{ Types of carpentry } & $F_{S, c a r}$ & $F_{\mathrm{Car}_{2} \mathrm{CO}_{2}}^{\mathrm{fab}}$ & $F_{\text {car } k W h}^{f a b}$ & $F_{c a r a g u a}^{f a b}$ & $F_{\text {car rosp }}^{\text {fah }}$ & $F_{\text {car resnp }}^{\text {fab }}$ & $F_{c a r}^{f a b} / m^{2}$ & $F_{\text {car }}^{\text {main }} / \mathrm{m}_{\mathrm{m}^{2}}$ & $F_{\mathrm{Car}_{2} \mathrm{CO}}^{\text {main }}$ & $F_{\text {carkWh }}^{\text {main }}$ \\
\hline $\mathrm{H} 1$ & & \multirow{3}{*}{0.17} & 592.05 & 1203.78 & 0.00 & 0.06 & 0.00 & 231.58 & 165.24 & 67.06 & 300.99 \\
\hline $\mathrm{H} 2$ & 4 & & 324.42 & 743.75 & 0.00 & 0.06 & 0.00 & 218.94 & 165.24 & 67.06 & 300.99 \\
\hline $\mathrm{H} 3$ & & & 37.46 & 169.85 & 0.00 & 0.06 & 0.00 & 247.90 & 409.43 & 71.88 & 326.93 \\
\hline
\end{tabular}

The equations to calculate a given impact ' $I_{x}$ ' during the manufacturing phase $\left(I_{x}^{f a b}\right)$ are obtained from the simple addition of three elements concerned with this impact 'Ix' produced by the roof assembly under study $\left(I_{x c u b}^{f a b}\right)$, the façade assembly $\left(I_{x f a c}^{f a b}\right)$, and the chosen type of carpentry $\left(I_{x c a r}^{f a b}\right)$. Each of these elements is composed of a surface factor Fs and of a factor depending on the building assembly selected for the impact (Table 5).

$$
I_{x}^{f a b}=I_{x c u b}^{f a b}+I_{x f a c}^{f a b}+I_{x c a r}^{f a b}
$$

Where:

$$
\begin{aligned}
& I_{x c u b}^{f a b}=\left(F_{S, c u b} \cdot F_{c u b, I_{X}}^{f a b}\right) \\
& I_{x f a c}^{f a b}=\left(F_{S, f a c} \cdot F_{f a c, I_{X}}^{f a b}\right) \\
& I_{x c a r}^{f a b}=\left(F_{S, c a r} \cdot F_{c a r, I_{X}}^{f a b}\right)
\end{aligned}
$$

The equations to calculate a given impact ' $I x^{\prime}$ ' in the maintenance phase $\left(I_{x}^{\text {main }}\right)$ are also obtained from the simple addition of three lineal elements concerned with this impact 'Ix' produced by the roof assembly under study $\left(I_{x c u b}^{\text {main }}\right)$, the façade assembly $\left(I_{x f a c}^{\operatorname{man}}\right)$, and the chosen type of carpentry $\left(I_{x c a r}^{\text {main }}\right)$. Each of these elements is composed of a factor Fs and of a factor depending on the building assembly selected for the impact (Table 5).

$$
I_{x}^{\text {main }}=I_{x c u b}^{\text {main }}+I_{x f a c}^{\text {main }}+I_{x c a r}^{\text {main }}
$$

Where:

$$
\begin{aligned}
& I_{x c u b}^{\text {main }}=\left(F_{S, c u b} \cdot F_{c u b, I_{X}}^{\text {main }}\right) \\
& I_{x f a c}^{\text {main }}=\left(F_{S, \text { fac }} \cdot F_{\text {fac }, I_{X}}^{\text {main }}\right) \\
& I_{x c a r}^{\text {main }}=\left(F_{S, \text { car }} \cdot F_{\text {car }, I_{X}}^{\text {main }}\right)
\end{aligned}
$$

As previously mentioned, the surface factor Fs is a datum that the planner calculates for each project. In Table 5 the Fs of the analysed case study is shown.

For example, to calculate the indicator 'equivalent $\mathrm{CO}_{2}$ emissions' (EmeqC2) during the manufacturing phase of an envelope composed of the combination of building assemblies codified as roof $\mathrm{C} 2$, façade $\mathrm{F} 1$, and carpentry $\mathrm{H} 1$ for a semi-detached house, the impact values for the indicator 'equivalent $\mathrm{CO}_{2}$ 
emissions' for the different building elements will be summed up, each of which are calculated as the multiplication of two factors whose values are taken from Table 5:

$$
\begin{aligned}
& E m_{\text {eqCO }}^{f a b}=\left\{\left(F_{S, C u b} \cdot F_{c u b, C O_{2}}^{f a b}\right)+\left(F_{S, f a c} \cdot F_{f a c, C O_{2}}^{f a b}\right)+\left(F_{S, C a r} \cdot F_{c a r, C O_{2}}^{f a b}\right)\right\} \\
& E m_{\text {eqCO }}^{f a b}=\{(0.72 \cdot 177.62)+(0.53 \cdot 67.20)+(0.17 \cdot 592.05)\}=264.16 \mathrm{Kg} \mathrm{eq} \mathrm{CO}_{2}
\end{aligned}
$$

In any environmental evaluation, a great deal of attention should be paid to uncertainty. For the manufacturing and maintenance phases, the uncertainty degree of the values obtained using equations [2] and [3] is associated to the uncertainty of the TCQGMA model. Since this uncertainty is not published, we have not indicated it in our model. This limitation should certainly be a topic of future research. On the other hand, estimating the impacts caused by other building assemblies requires increasing the scope of information within the model, since for the moment it only has the building assemblies described in Table 3 .

\subsubsection{Obtaining the equations for the use phase impacts.}

The equations for the use phase were obtained by producing a multiple linear regression model, using the factors analysed in the case under study, i.e. climate zone, building orientation, three types of roofing, five types of façade and three types of carpentry, as the explanatory variables, and the impacts during the use phase were taken as dependent variables.

Table 6 summarises part of the data used to calculate the regression model. The matrix is divided into two blocks: the block on the left shows the explanatory variables used to obtain the formula for each indicator, while the block on the right shows the dependent variables for the impacts that were evaluated. The first block contains 10 columns: the first lists the combinations of the building assemblies that were evaluated and the other nine columns contain a binary coding for each of the variables used as input data to obtain the equations. The first group of variables is made up of the building assemblies that will form the combinations of the envelope that were used in this research study. Each column is identified by means of letters and numbers that stand for the type of variable.

The orientation of the building envelope is identified by means of two letters (NE: North-easterly Orientation, and SE: South-easterly Orientation) and the climate zone is identified by a letter and a number (B3 and E1). The binary coding allows the building assemblies that make up each combination of the envelope to be identified.

\begin{tabular}{|c|c|c|c|c|c|c|c|c|c|c|c|c|c|c|c|}
\hline \multirow{3}{*}{$\begin{array}{c}\text { TYPE } \\
\\
\text { SEMI- } \\
\text { DETACHED } \\
\text { HOUSE }\end{array}$} & \multicolumn{11}{|c|}{ VARIABLES } & \multicolumn{4}{|c|}{ ENVIRONMENTAL IMPACTS IN THE USE PHASE } \\
\hline & \multirow{2}{*}{ 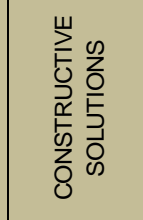 } & \multicolumn{2}{|c|}{ A } & \multicolumn{3}{|c|}{ 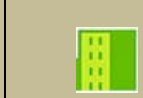 } & 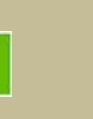 & \multicolumn{2}{|c|}{40} & \multirow{2}{*}{ 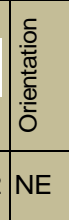 } & \multirow{2}{*}{ 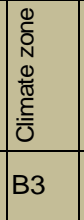 } & \multirow{2}{*}{$\begin{array}{c}\begin{array}{c}\text { Heating } \\
\text { emissions }\end{array} \\
(\mathrm{kg} \\
\left.\mathrm{CO}_{2} / \mathrm{m}^{2}\right)\end{array}$} & \multirow{2}{*}{\begin{tabular}{|c}
$\begin{array}{c}\text { Air } \\
\text { conditioning } \\
\text { emissions }\end{array}$ \\
$\left(\mathrm{kg} \mathrm{CO}_{2} / \mathrm{m}^{2}\right)$
\end{tabular}} & \multirow{2}{*}{\begin{tabular}{|c}
$\begin{array}{c}\text { Heating } \\
\text { consumption }\end{array}$ \\
$\left(\mathrm{kWh} / \mathrm{m}^{2}\right)$
\end{tabular}} & \multirow{2}{*}{$\begin{array}{c}\begin{array}{c}\text { Air } \\
\text { conditioning } \\
\text { consumption }\end{array} \\
\left(\mathrm{kWh} / \mathrm{m}^{2}\right)\end{array}$} \\
\hline & & C1 & C2 & F1 & F2 & F3 & $\mathrm{F} 4$ & $\mathrm{H} 1$ & $\mathrm{H} 2$ & & & & & & \\
\hline & $\mathrm{C} 1 \mathrm{~F} 1 \mathrm{H} 1$ & 1 & 0 & 1 & 0 & 0 & 0 & 1 & 0 & 1 & 1 & 8.70 & 4.80 & 42.90 & 19.20 \\
\hline & C1 F2 H1 & 1 & 0 & c & 1 & 0 & 0 & 1 & 0 & 1 & 1 & 8.50 & 4.80 & 42.20 & 19.20 \\
\hline & C1 F3 H1 & 1 & 0 & c & 0 & 1 & 0 & 1 & 0 & 1 & 1 & 7.70 & 4.60 & 38.10 & 18.60 \\
\hline & $\mathrm{C} 1 \mathrm{~F} 4 \mathrm{H} 1$ & 1 & 0 & c & 0 & 0 & 1 & 1 & 0 & 1 & 1 & 8.50 & 5.00 & 42.10 & 19.90 \\
\hline & C1 F5 H1 & 1 & 0 & c & 0 & 0 & 0 & 1 & 0 & 1 & 1 & 5.90 & 6.80 & 27.70 & 27.30 \\
\hline & $\mathrm{C} 2 \mathrm{~F} 1 \mathrm{H} 1$ & c & 1 & 1 & 0 & 0 & 0 & 1 & 0 & 1 & 1 & 8.90 & 4.80 & 44.20 & 19.30 \\
\hline & $\mathrm{C} 2 \mathrm{~F} 2 \mathrm{H} 1$ & c & 1 & c & 1 & 0 & 0 & 1 & 0 & 1 & 1 & 8.70 & 4.90 & 43.40 & 19.70 \\
\hline & C2 F3 H1 & c & 1 & c & 0 & 1 & 0 & 1 & 0 & 1 & 1 & 7.80 & 4.80 & 38.50 & 19.40 \\
\hline & $\mathrm{C} 2 \mathrm{~F} 4 \mathrm{H} 1$ & c & 1 & c & 0 & 0 & 1 & 1 & 0 & 1 & 1 & 8.80 & 4.90 & 43.60 & 19.60 \\
\hline & $\mathrm{C} 2 \mathrm{~F} 5 \mathrm{H} 1$ & c & 1 & c & 0 & 0 & 0 & 1 & 0 & 1 & 1 & 5.60 & 6.70 & 27.70 & 26.90 \\
\hline & C3 F1 H1 & c & 0 & 1 & 0 & 0 & 0 & 1 & 0 & 1 & 1 & 8.50 & 4.70 & 42.30 & 18.70 \\
\hline
\end{tabular}

Table 6 showing an extract of the impacts in the use phase

The formula for each indicator was obtained by selecting the data from the column for the corresponding indicator (dependent variable) that is to be calculated and the data corresponding to the columns for all the explanatory variables (types of roofing, façade and carpentry, solar orientation, and climate zone).

As an example, for the indicator 'equivalent $\mathrm{CO}_{2}$ emissions', the coefficients obtained for the regression model are shown in Table 7.

Table 7 Regression model coefficients for the indicator 'equivalent $\mathrm{CO}_{2}$ emissions'

\begin{tabular}{|l|l|l|l|l|l|l|l|l|l|l|l|}
\hline Variable & BE & NE & H2 & H1 & F4 & F3 & F2 & F1 & C2 & C1 & Independent \\
\hline
\end{tabular}




\begin{tabular}{|c|c|c|c|c|c|c|c|c|c|c|c|}
\hline & & & & & & & & & & & term \\
\hline $\begin{array}{l}\text { Regression } \\
\text { coefficient }\end{array}$ & -18.06 & 0.05 & -0.07 & 0.20 & 2.31 & 0.84 & 2.28 & 2.62 & 0.67 & 0.49 & 23.7 \\
\hline
\end{tabular}

The regression model is used to obtain the value of the coefficients for each of the dependent variables shown in Table 8 . The first column names the variables. The following columns show the numerical values of the four impact factors of the use phase (the independent term and the corrective amounts) and the standard error of the regression model in absolute and relative terms. Such standard error provides a measure of the model uncertainty.

Table 8. Corrective amounts of each impact in the use phase

\begin{tabular}{|c|c|c|c|c|c|}
\hline & & $\begin{array}{l}\text { Heating } \\
\text { emissions }\end{array}$ & $\begin{array}{l}\text { Air conditioning } \\
\text { emissions }\end{array}$ & $\begin{array}{c}\text { Heating } \\
\text { consumption }\end{array}$ & $\begin{array}{c}\text { Air } \\
\text { conditioning } \\
\text { consumption } \\
\end{array}$ \\
\hline \multicolumn{2}{|c|}{ Independent term } & 23.7 & 1.58 & 116.4 & 6.28 \\
\hline \multicolumn{2}{|c|}{ Response standard error } & \pm 0.57 & \pm 0.31 & \pm 2.20 & \pm 1.34 \\
\hline \multicolumn{2}{|c|}{$\begin{array}{l}\text { Relative response } \\
\text { standard error }\end{array}$} & $3 \%$ & $11 \%$ & $3 \%$ & $12 \%$ \\
\hline \multicolumn{6}{|c|}{ VARIABLES } \\
\hline \multicolumn{2}{|c|}{ Types of roofing } & $F_{\mathrm{Cub}, \mathrm{CO}_{2} \mathrm{Cal}}^{\mathrm{usO}}$ & $F_{\mathrm{Cub}, \mathrm{CO}_{2} \text { ref }}^{\mathrm{usO}}$ & $F_{\text {cub,kWhcal }}^{\text {usu }}$ & $F_{\text {cub }, i k W h r e f}^{u s o}$ \\
\hline \multirow{3}{*}{\begin{tabular}{l|} 
C1 \\
C2 \\
C3 \\
\end{tabular}} & \multirow{3}{*}{ 2) } & 0.49 & 0.09 & 1.44 & 0.48 \\
\hline & & 0.67 & 0.08 & 3.21 & 0.46 \\
\hline & & 0 & 0 & 0 & 0 \\
\hline \multicolumn{2}{|c|}{ Types of façade } & $F_{\text {fac, } \mathrm{CO}_{2} \mathrm{Cal}}^{\mathrm{uso}}$ & $\mathrm{F}_{\mathrm{car}, \mathrm{CO}_{2} \mathrm{ref}}^{\mathrm{uSO}}$ & $F_{\text {fac }}^{u \text { kWh }}$ Whal & $F_{f a c, k w h r e f}^{u}$ \\
\hline $\mathrm{F} 1$ & \multirow{5}{*}{$\sqrt{\vdots}:$} & 2.62 & -1.44 & 14.32 & -5.78 \\
\hline $\mathrm{F} 2$ & & 2.28 & -1.45 & 12.93 & -5.81 \\
\hline F3 & & 0.84 & -1.49 & 5.36 & -6.02 \\
\hline $\mathrm{F} 4$ & & 2.31 & -1.37 & 12.73 & -5.54 \\
\hline $\mathrm{F} 5$ & & 0 & 0 & 0 & 0 \\
\hline \multicolumn{2}{|c|}{ Types of carpentry } & $\mathrm{F}_{\mathrm{Car}, \mathrm{CO}_{2} \mathrm{Cal}}^{\mathrm{uSO}}$ & $\mathrm{F}_{\text {car }, \mathrm{CO}_{2} \mathrm{ref}}^{\text {uso }}$ & $F_{\text {car kWW }}$ Whol & $F_{\text {Gar, kWh }}^{\text {uso }}$ \\
\hline $\mathrm{H} 1$ & \multirow{3}{*}{ A $\#$} & 0.2 & -0.08 & 1.27 & -0.3 \\
\hline $\mathrm{H} 2$ & & -0.07 & -0.03 & 0.27 & -0.23 \\
\hline $\mathrm{H} 3$ & & 0 & 0 & 0 & 0 \\
\hline \multicolumn{2}{|r|}{ Climate zone } & $F_{Z, C O}^{u s o}$ cai & $F_{Z, C O_{2} r e_{j}^{f}}^{u S O}$ & $F_{7, k \text { rusa }}^{\text {ruscel }}$ & $F_{Z, k w h r e f}^{\text {zuso }}$ \\
\hline B3 & \multirow[b]{2}{*}{5} & -18.06 & 4.66 & -89.4 & 18.65 \\
\hline E1 & & 0 & 0 & 0 & 0 \\
\hline \multicolumn{2}{|r|}{ Orientation } & $\mathrm{F}_{\mathrm{Or}, \mathrm{CO}_{2} \mathrm{Cat}}^{\mathrm{uso}}$ & $\mathrm{F}_{\mathrm{Or}, \mathrm{CO}_{2} \mathrm{ref}}^{\mathrm{usO}}$ & $F_{\text {Or, } \mathrm{u} W \text { Wrcal }}^{\text {uso }}$ & For,lewhref \\
\hline SE & \multirow{2}{*}{$\frac{4}{x}$} & 0 & 0 & 0 & 0 \\
\hline $\mathrm{NE}$ & & 0.05 & 0.01 & 0.1 & -0.01 \\
\hline
\end{tabular}

The values from Table 8 , obtained by applying a linear regression model to the impact values of the use phase, are taken to produce the equations of the regression models that were obtained. The independent term of each equation is established by the regression model, and the corrective amount of each variable is replaced in each case according to the roofing, façade and carpentry option chosen by the planner and depending on the building orientation and the climate zone (Table 8).

The standard error of the estimated impact for the equations is obtained directly from the Excel sheet and is indicated in Table 8 . The value of this error indicates the uncertainty interval of the impact estimation. The equation to calculate the impacts in the use phase is defined as follows:

$$
I_{x}^{u s o}=\left(\left(T I_{x}+F_{Z, \mathrm{I} x}^{u s o}+F_{O r, \mathrm{I} x}^{u s o}+F_{c u b, \mathrm{I} x}^{u s o}+F_{f a c, \mathrm{I} x}^{u s o}+F_{c a r, \mathrm{I} x}^{u s o}\right) \pm s e y\right) \cdot N^{\text {lifetime }}
$$

Where:

$I_{x}^{u s o}=$ Impact 'Ix' due to the use phase

$T I_{x}=$ independent term for each impact 
$F_{i, \mathrm{I} x}^{u s o}=$ Corrective amount of variable ' $\mathrm{i}$ ' for each impact ' $\mathrm{x}$ '

Sey = estimation error, measure of the associated uncertainty

$N^{\text {lifetime }}=$ lifetime considered

For example, to calculate the indicator 'equivalent $\mathrm{CO}_{2}$ emissions' during the use phase of the semidetached house in climate zone B3 and solar orientation NE, with an envelope composed of roof C2, façade F1, and carpentry H1, for a lifetime of 50 years, the values in Table 8 are used in equation [4]:

$$
E m_{\text {eq, } \mathrm{CO}_{2} \mathrm{cal}}^{\text {uso }}=((23.7-18.06+0.05+0.67+2.62+0.2) \pm 0.57) \cdot 50=[430.5,487.5]{\mathrm{Kg} \mathrm{eq} \mathrm{CO}_{2}}
$$

\subsection{Obtaining a corrective factor for the estimation of impacts in other types of buildings}

The equations previously proposed to estimate sustainability indicators for the building envelope were obtained from data about semi-detached houses. To extrapolate this model on other types of residential buildings, it would be necessary to undertake all the steps previously followed for the case of the semidetached houses with the other dwelling types, updating and adapting the previous tables to the type under consideration. However, as a first rough approach to this matter, a corrective factor for different types of residential buildings to be applied to previous equations is calculated next.

For this, eight combinations of building assemblies for the envelope for two types of buildings have been considered: a five-story block of flats with two dwellings per floor and a total of $1,324.7 \mathrm{~m}^{2}$ of net area, and a single story detached house of $107.47 \mathrm{~m}^{2}$ of net area.

As can be seen in Figure 3 the distance between the values of one type of dwelling and other types is not constant, but it shows certain trends when they are analysed considering the climate zones, i.e. it remains quite similar for the same climate zone (E1 or B3). The followed approach was to calculate a mean value for the difference between the semi-detached house and the other building types to use it as corrective amount, as well as an error that establishes the confidence interval for the spread of data in relation to the calculated mean. This was done for each of the four impact values and for the climate zones E1 and B3. The confidence level for the calculation of the confidence interval was of $95 \%$. The error interval was obtained multiplying by 1.96 the value of the standard deviation divided by the square root of the sample size, consisting of 4 data, as can be seen in Table 9. This way a first corrective factor was obtained, to be used to multiply the impact value for other residential building types (different to semidetached house), applying the error interval corresponding to each impact and climate zone.
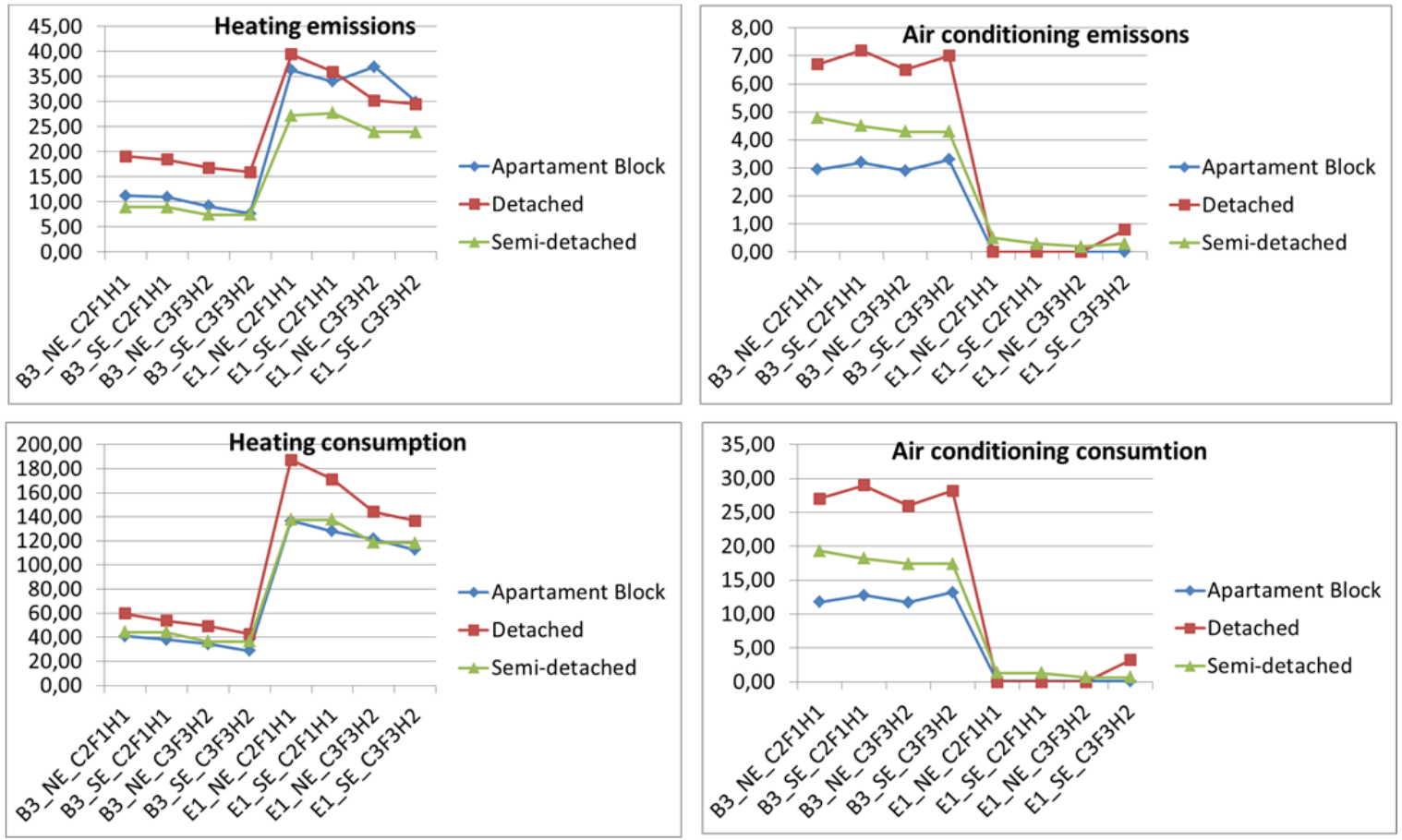

Figure 3 Comparison of impacts in the use phase for different type of dwellings 
This corrective factor is obtained by calculating the average distance between each of the impacts produced during the use phase of the apartment block and by the detached house with respect to the impacts produced in this same phase by the semi-detached house used as a study case, each climate zone being considered separately. This value is the factor type of housing F_tviv that can be seen in Table 9.

Table 9 Corrective factor according to the type of dwelling

\begin{tabular}{|c|c|c|c|c|}
\hline TYP & \multicolumn{4}{|c|}{ CORRECTIVE FACTOR ACCORDING TO TYPE } \\
\hline \multirow[t]{3}{*}{$\begin{array}{c}\text { Semi- } \\
\text { detached }\end{array}$} & $F_{t w i v,} \mathrm{CO}_{2 \text { s:at }}$ & $F_{\text {tviv, }} \mathrm{CO}_{2 \mathrm{r} \otimes f}$ & $F_{t v i v, k W h_{\text {t:ul }}}$ & $F_{\text {twiw } k W l_{\mathrm{r}}}$ \\
\hline & $1 \pm 0.00$ & $1 \pm 0.00$ & $1 \pm 0.00$ & $1 \pm 0.00$ \\
\hline & $1 \pm 0.00$ & $1 \pm 0.00$ & $1 \pm 0.00$ & $1 \pm 0.00$ \\
\hline \multirow[t]{3}{*}{$\begin{array}{c}\text { Apartament } \\
\text { Block }\end{array}$} & $F_{\text {tviv }} \mathrm{CO}_{2 \mathrm{cal}}$ & $F_{\text {tviv }, \mathrm{CO}_{2} \text { reft }}$ & $F_{\text {Cviv,kWh cal }}$ & $F_{t v i v, k}^{2} W_{n \in f}$ \\
\hline & $1.18 \pm 0.10$ & $0.69 \pm 0.06$ & $0.88 \pm 0.07$ & $0.69 \pm 0.06$ \\
\hline & $1.34 \pm 0.14$ & $0 \pm 0.00$ & $0.98 \pm 0.04$ & $0.11 \pm 0.04$ \\
\hline \multirow[t]{3}{*}{ Detached } & $F_{\text {Lviv,CO }}$ & $F_{t v t v, \mathrm{CO}_{2} \mathrm{ref}}$ & $F_{t v i v, k W h_{c a l}}$ & $F_{t v t v, k W h_{r \& f}}$ \\
\hline & $1.31 \pm 0.09$ & $1.53 \pm 0.10$ & $1.27 \pm 0.09$ & $1.53 \pm 0.10$ \\
\hline & $1.30 \pm 0.10$ & $0.67 \pm 1.31$ & $1.24 \pm 0.08$ & $0.29 \pm 0.58$ \\
\hline
\end{tabular}

As can be seen in Table 9, the corrective factor of $\mathrm{CO}_{2}$ emissions to cool the dwellings of the block of flats is of zero value because the calculated impact has exactly the same value that in the semidetached house. It is also worth mentioning that in the single story detached house the error interval is higher than the mean of the corrective factor for both, the emissions and the consumption due to cooling. This is because only one of the combinations of the envelope assemblies presented significant differences between the single story detached house and the semi-detached house, and therefore the standard deviation and consequently the error interval are higher than the mean.

The equation to estimate the impacts in the use phase is obtained multiplying equation [4] by the dwelling type factor Ftviv:

$I_{x}^{u s o}=\left(\left(T I_{x}+F_{Z, \mathrm{I} x}^{u s o}+F_{o r, \mathrm{I} x}^{u s o}+F_{c u b, \mathrm{I} x}^{u s o}+F_{f a c, \mathrm{I} x}^{u s o}+F_{c a r, \mathrm{I} x}^{u s o}\right) \pm s e y\right) \cdot N^{\text {lifetime }} \cdot F_{t v i v, I_{X}}$

Where

$I_{x}^{u s o}=$ Impact 'Ix' due to the use phase

$T I_{x}=$ independent term for each impact

$F_{i, \mathrm{Ix}}^{u s o}=$ Corrective amount of variable ' $\mathrm{i}$ ' for each impact ' $\mathrm{Ix}$ '

Sey $=$ estimation error, measure of the associated uncertainty

$N^{\text {vida util }}=$ lifetime considered

$F_{\text {tviv,IX}}=$ Corrective factor depending on the dwelling type and impact type

For example, to calculate the indicator 'equivalent $\mathrm{CO}_{2}$ emissions' during the use phase due to heating, of an envelope composed of roof $\mathrm{C} 2$, façade $\mathrm{F} 1$, carpentry $\mathrm{H} 1$ of a dwelling in a block of flats in climate zone B3 and orientation NE, for a lifetime of 50 years, equation [5] will be used using the following values:

$$
E m_{\text {eq, } \mathrm{CO}_{2} \mathrm{cal}}^{\text {uso }}=[(23,7-18,06+0,05+0,67+2,62+0,2) \pm 0,57] \times 50 \times(1,18 \pm 0,10)=
$$

$=[503,69 ; 580,13] \mathrm{Kg}$ eq $\mathrm{CO}_{2}$

The same applies to obtain equations for the rest of indicators for the use phase.

The value of the equation is multiplied by the lifetime considered and by the corrective factor due to the dwelling type, allowing to roughly estimate the impact with other building types.

The corrective factors and amounts of the evaluation model are only valid for the defined building assemblies and conditions. It will be necessary in the future to broaden the number of building assemblies 
solutions to properly aid planners in the decision making process. However, the defined equations will remain the same when more data is added. The equations and the procedure to obtain the factors and amounts constitute the essential elements of the model proposed here and the main contribution of the paper since they represent the method for the easy estimation of impacts of building envelopes considering the whole life cycle.

\subsection{Validation of the model}

In the first place, it must be pointed out that mathematically speaking, an equation obtained through lineal regression fits the data when the R-squared $\left(\mathrm{r}^{2}\right)$ is close to value 1 . In this case, the regression model obtained is considered to be sufficiently reliable, since the $r^{2}$ values of the regressions that were performed and obtained by means of an Excel sheet, are very close to 1, the lowest $r^{2}$ being 0.9819 ; all the regression models therefore fit the real data quite well (Table 10).

Additionally, we have checked the appropriateness of the model by means of the F-statistic, which makes it possible to check whether the variables used for the regression model really explain the value of the impacts that are analysed. When there is no relation between the independent variables, xi and the dependent one $\mathrm{y}$, the value of the F-statistic is below the critical $\mathrm{F}$ value, which is obtained from $\mathrm{F}$ distribution tables. This distribution depends on the degrees of freedom $n$ and $N, n$ being equal to the number of degrees of freedom and $\mathrm{N}$ equal to the size of the sample minus the number of degrees of freedom (df). Hence, for the regression models that were produced:

$$
\begin{aligned}
& \mathrm{N}=180 \\
& \mathrm{df}=169 \\
& \mathrm{n}=\mathrm{N}-\mathrm{df}=180-169=11 \\
& \text { The critical } \mathrm{F} \text { (Fcrit) value for an error } \alpha=0.05 \text { is } 1.88 .
\end{aligned}
$$

Table 10 shows the $\mathrm{r}^{2}$ value and the $\mathrm{F}$ distribution for each of the regression models. The value of $\mathrm{F}$ in each equation is much higher than the Fcrit (1.88), thereby indicating that the variables used explain the final impact value well. As a result, the model equation developed to evaluate the impact of $\mathrm{CO}_{2}$ emissions and energy consumptions in the use phase is considered to be valid.

Table 10 Values of $r^{2}$ and the $F$ distribution for each of the regression models.

\begin{tabular}{|l|l|l|l|l|}
\hline Impacts use phase & $E m_{e q, \mathrm{CO}_{2} \text { cal }}^{\text {uso }}$ & $\mathrm{Em}_{\text {eq, } \mathrm{CO}_{2} \text { ref }}^{\text {uso }}$ & Con $_{\mathrm{kWh} \text { cal }}^{\text {uso }}$ & Con $_{\mathrm{epkWh} \text { ref }}^{\text {uso }}$ \\
\hline $\mathrm{r}^{2}$ & 0.9963 & 0.9841 & 0.9978 & 0.9819 \\
\hline $\mathrm{F}$ & $4,551.9$ & $1,048.84$ & $7,530.38$ & 917.003 \\
\hline
\end{tabular}

Ideally, evidence of validation of these model data against real performance of the types of buildings under consideration should be provided. In fact, within the building industry, there is an increasing concern about the mismatch between the predicted performance of buildings environmental behaviour and the actual measured performance. However, studying that gap is beyond the scope of the present paper because this represents by itself a vast topic of research. For the moment this work studies the level of uncertainty associated to the process of obtaining of equations by means of checking how close the values obtained with the equations for the use phase (i.e., the equations obtained through lineal regression) are to the values obtained with the official simulation software (i.e. LIDER and CALENER VYP). In the future, it will be interesting to compare them also with real building data, when they exist.

For the comparison between the simplified method here proposed and the simulation software, the percentage value of the deviation for 180 combinations was studied. In the following the results of testing the level of error of the model are discussed:

With regard to the manufacturing and installation phase, the relative error did not exceed $0.46 \%$, the average relative error being $0.31 \%$.

As regards the maintenance phase, the relative error reached $11.20 \%$ for some values, although it can be seen that the average is $7.15 \%$ and that the error always has a negative sign. This confirms the idea that the error is always produced in the same sense, that is to say, the model would always be below the real value and the error is therefore within acceptable values.

As far as the use phase is concerned, the relative error in the indicator Equivalent $\mathrm{CO}_{2}$ Emissions ranges between values of 0.15 and $10.5 \%$ in most cases. Likewise, it can be seen that the average of the relative 
errors is $1.96 \%$ and that the relative error of a particular building assembly holds the same sign and is similar in all the different types. The estimated values given by the indicator can therefore be considered acceptable.

In this same use phase the relative error in the indicator Equivalent $\mathrm{CO}_{2}$ Emissions due to emissions from air conditioning cannot be tested in several of the results because they are real values that are insignificant (close to 0), which raises the relative value of the indicator sharply in percentage terms.

Taking all the above into account, the model developed here is considered to be valid.

\subsection{Creation of the matrix in Excel to implement the model}

Once the equations had been obtained and their validity tested, they were implemented in a number of matrices in Excel. This allows different alternative designs to be chosen for the building envelope in different climate zones and orientations in three types of buildings, so that the estimated values of the impacts generated in each of the phases of the life cycle of the building can be shown automatically.

The first step is to develop a calculation matrix, which is divided into two parts: the left-hand side of the matrix contains the columns of data in which the user can select the different variables corresponding to the construction assemblies, orientation and climate zone. There is a column to incorporate the Fs (Surface factor) value corresponding to the proportional share of the surface area of each element in the envelope per square metre of net floor area of the building.

The right-hand part of the matrix contains the columns of the results and is divided into three blocks, one for each of the phases of the life cycle of the building evaluated: the manufacturing and installation phase subdivided into six columns, the maintenance phase subdivided into four columns and the use phase subdivided into six columns. Each column contains an impact in its corresponding phase and shows the name of the indicator and the corresponding units according to the type of impact per square metre of usable floor area in the dwelling.

The planner can use this calculation matrix by selecting the type of dwelling in the first column and using the second column to indicate the surface factor, Fs. Furthermore, the user can also select the climate zone and the building orientation.

The estimated value of the impacts is obtained because the equations developed for each indicator are linked to the corresponding cell of the calculation matrix (Figure 3.3). Columns belonging to the same indicator are identified with the same colour in the different phases of the life cycle. The user can estimate the value of the impacts in real time and can compare different design options easily. Thus, table 11 and table 12 show the calculation matrix with the results obtained for the options that were selected. The estimated values for the impacts are the mean of the extreme values of the uncertainty interval presented in section 3.1.1.

Table 11 Calculation matrix: Result of the estimated values of each impact in the manufacturing phase and maintenance phase of the life cycle

\begin{tabular}{|c|c|c|c|c|c|c|c|c|c|c|c|c|c|c|c|c|c|c|c|}
\hline \multirow[t]{4}{*}{ BUILD TYPE } & \multicolumn{8}{|c|}{ VARIABLES } & \multicolumn{7}{|c|}{ MANUFACTURING PHASE } & \multicolumn{4}{|c|}{ MAINTENANCE PHASE } \\
\hline & \multirow{2}{*}{\multicolumn{2}{|c|}{ 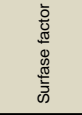 }} & \multicolumn{4}{|c|}{ Constructive elements } & \multirow{2}{*}{ 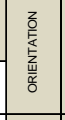 } & \multirow{2}{*}{ 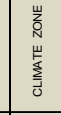 } & \multirow{2}{*}{\begin{tabular}{|l}
$\begin{array}{l}\text { Eq. } \mathrm{CO}_{2} \\
\text { emissions }\end{array}$ \\
$E m_{e q C 2_{3}}^{f a b}$ \\
\end{tabular}} & \multirow{2}{*}{\begin{tabular}{|c|}
$\begin{array}{c}\text { Energy } \\
\text { consump }\end{array}$ \\
Conn tazksz
\end{tabular}} & \multirow{2}{*}{ 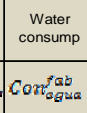 } & \multirow{2}{*}{\begin{tabular}{|c|}
$\begin{array}{c}\text { Non } \\
\text { Hazardous } \\
\text { waste }\end{array}$ \\
$G e n_{r e s m p}^{\text {fab }}$ \\
\end{tabular}} & \multirow{2}{*}{\begin{tabular}{|c|}
$\begin{array}{c}\text { Hazardous } \\
\text { waste }\end{array}$ \\
Cen fab \\
gesp
\end{tabular}} & \multirow{2}{*}{ 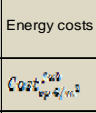 } & \multirow{2}{*}{\begin{tabular}{|c|}
$\begin{array}{c}\text { Investment } \\
\text { costs }\end{array}$ \\
$\mathrm{fnst}_{\mathbf{z} / \mathrm{m}^{2}}^{\mathrm{fab}}$ \\
\end{tabular}} & \multirow{2}{*}{\begin{tabular}{|l} 
Eq. $\mathrm{CO}_{2}$ \\
emissions
\end{tabular}} & \multirow{2}{*}{$\begin{array}{c}\begin{array}{c}\text { Energy } \\
\text { consump }\end{array} \\
\text { Con maph }\end{array}$} & \multirow{2}{*}{\begin{tabular}{|c|}
$\begin{array}{c}\text { Energy } \\
\text { costs }\end{array}$ \\
Contsegs \\
\end{tabular}} & \multirow{2}{*}{\begin{tabular}{|c}
$\begin{array}{c}\text { Retrofit } \\
\text { costs }\end{array}$ \\
Cost $_{\mathbf{Q} / m}^{\text {man }}$
\end{tabular}} \\
\hline & & & in & & & 4 & & & & & & & & & & & & & \\
\hline & Type & Fs & $\mathrm{C}_{1} \mathrm{C}_{2} \mathrm{C}_{3}$ & & \begin{tabular}{l|l|l}
$F 2$ & $F 3$ & $F 4$ \\
\end{tabular} & $\begin{array}{ll}=5 & \mathrm{H} 1 \\
\mathrm{H} 2 & \mathrm{H} 3 \\
\mathrm{H} 3\end{array}$ & NE SE & B $B 31$ & $\mathrm{~kg} \mathrm{CO}_{2} / \mathrm{m}^{2}$ & $\mathrm{kWh} / \mathrm{m}^{2}$ & $\mathrm{~m}^{3 /} / \mathrm{m}^{2}$ & $\mathrm{~kg} / \mathrm{m}^{2}$ & $\mathrm{~kg} / \mathrm{m}^{2}$ & $\epsilon / m^{2}$ & $\epsilon / m^{2}$ & $\mathrm{~kg} \mathrm{CO}_{2} / \mathrm{m}^{2}$ & $\mathrm{kWh} / \mathrm{m}^{2}$ & $\epsilon / \mathrm{m}^{2}$ & $€ / \mathrm{m}^{2}$ \\
\hline $\begin{array}{r}\text { SEMDET } \\
\frac{\text { BLOCK }}{\text { DETACHED }}\end{array}$ & 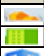 & 0.72 & & & & & & & 264.16 & 0.17 & 0.03 & 23.74 & 0.10 & 119.71 & 197.05 & 85.88 & 182.10 & 32.98 & 107.37 \\
\hline $\begin{array}{c}\text { DETACHED } \\
\text { SEMIDET }\end{array}$ & $\approx$ & $\begin{array}{l}1.00 \\
0.72 \\
\end{array}$ & & & & & & & & & & & & & & & & & \\
\hline $\begin{array}{r}\text { BLOCK } \\
\text { DETACHED } \\
\end{array}$ & 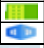 & $\begin{array}{l}0.23 \\
1.00 \\
\end{array}$ & & & & & & & 222.75 & 0.17 & 0.05 & 13.21 & 0.08 & 98.18 & 161.04 & 66.57 & 152.03 & 27.54 & 88.49 \\
\hline SEMIDET & $=$ & 0.53 & & & & & & & & & & & & & & & & & \\
\hline BLOCK & iil & 0.63 & & & & & & & 165.53 & 0.14 & 0.02 & 18.15 & 0.04 & 75.11 & 129.54 & 39.22 & 89.95 & 75.11 & 58.88 \\
\hline - DETACHED & 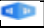 & 1.44 & & & & & & & & & & & & & & & & & \\
\hline SEMIDET & $\infty$ & 0.53 & & & & & & & & & & & & & & & & & \\
\hline BLOCK & II & 0.63 & & & & & & & 126.81 & 0.14 & 0.03 & 9.24 & 0.03 & 60.86 & 110.67 & 33.06 & 80.35 & 14.55 & 52.85 \\
\hline $\begin{array}{l}\text { DETACHED } \\
\text { SEMIDET }\end{array}$ & 《. & 1.44 & & & & & & & & & & & & & & & & & \\
\hline$\frac{\text { SEMIDET }}{\text { BLOCK }}$ & $1=$ & 1.00 & & & & & & & & & & & & & & & & & \\
\hline $\begin{array}{l}\text { BLOCKK } \\
\text { DETACHED } \\
\end{array}$ & $\infty$ & $\begin{array}{l}1.44 \\
0.25\end{array}$ & & & & & & & 421.17 & 0.25 & 0.06 & 49.11 & 0.13 & 197.06 & 346.47 & 129.56 & 266.24 & 48.22 & 167.34 \\
\hline SEMIDET & $=$ & 1.00 & & & & & & & & & & & & & & & & & \\
\hline BLOCK & III & 1.44 & & & & & & & 356.44 & 0.25 & 0.08 & 26.01 & 0.11 & 165.65 & 288.54 & 102.73 & 224.48 & 40.66 & 141.12 \\
\hline 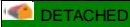 & & 0.25 & & & & & & & & & & & & & & & & & \\
\hline
\end{tabular}

Table 12 Calculation matrix: Result of the estimated values of each impact in the use phase of the life cycle 


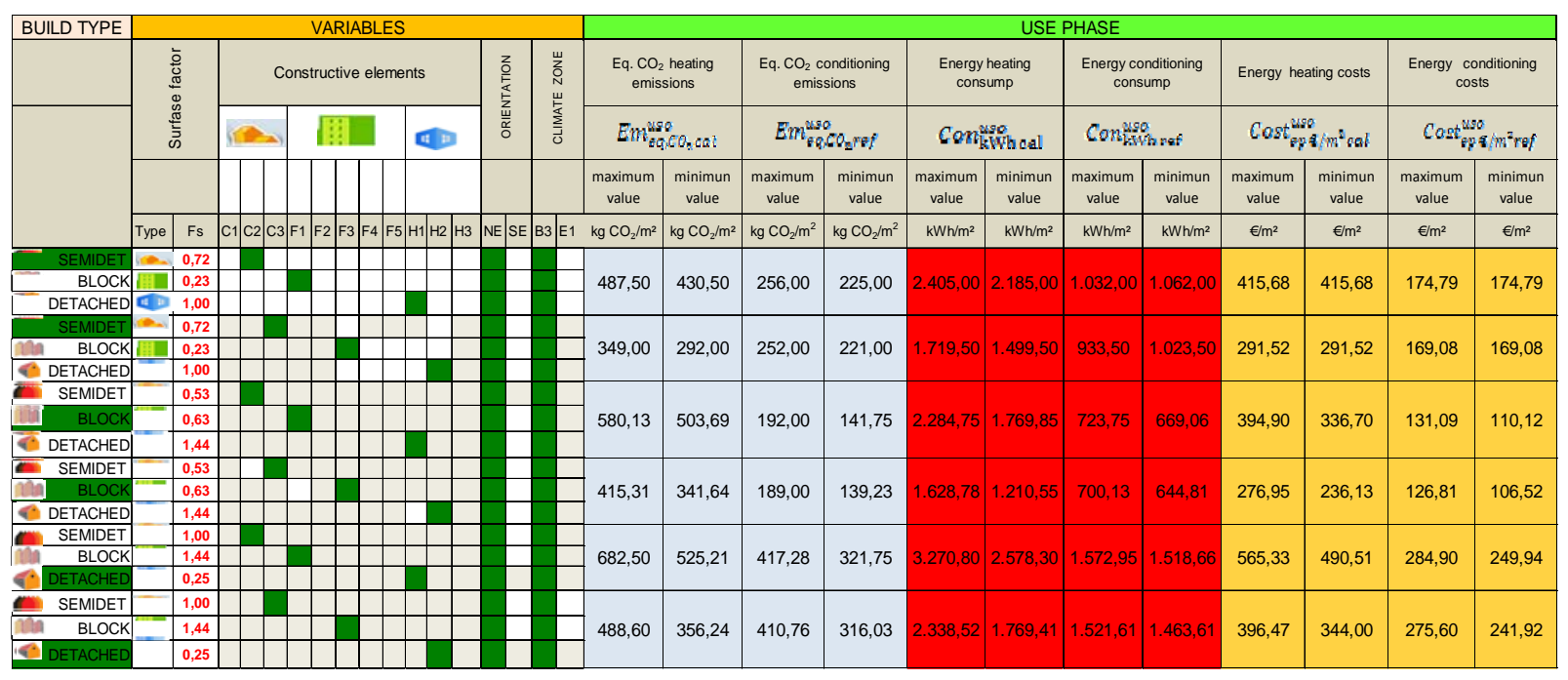

The environmental impact scores of life cycle assessments are often presented in units that are difficult to grasp, such as equivalent $\mathrm{CO} 2$ emissions. One way to make their interpretation easier is to normalise them, that is to say, to divide the scores by a reference score. Normalising the data linearly in such a way that the minimum and maximum values of the indicators shift to the values 0 and 1 , respectively, and all the other indicators take on relative values within the dimensionless range $(0,1)$, allows to easily compare all the values estimated with the model. The normalisation functions were defined based on the idea that the higher the value of the indicator is, the lower the impact will be, that is to say, they are inversely related.

Table 13 and table 14 show the normalisation matrix with the results obtained following the normalisation of all the impacts in Figure 3.3. This matrix has the same structure of rows and columns as the calculation matrix and the columns have the same colour as in the calculation matrix. This way, tables 13-14 show the normalised values of the impact in a 0 to 1 scale.

Table 13 Normalisation matrix: Result of the normalised values of each impact in the manufacturing phase and retrofit phase of the life cycle

\begin{tabular}{|c|c|c|c|c|c|c|c|c|c|c|c|c|c|c|c|c|c|c|}
\hline \multirow[t]{4}{*}{ BUILD TYPE } & \multicolumn{7}{|c|}{ VARIABLES } & \multicolumn{7}{|c|}{ MANUFACTURING PHASE } & \multicolumn{4}{|c|}{ RETROFIT PHASE } \\
\hline & \multirow{2}{*}{\multicolumn{2}{|c|}{ 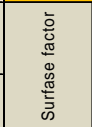 }} & \multicolumn{3}{|c|}{ Constructive elements } & \multirow{2}{*}{ 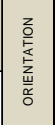 } & \multirow{2}{*}{ 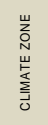 } & \multirow{2}{*}{ 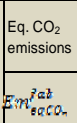 } & \multirow{2}{*}{\begin{tabular}{|c|}
$\begin{array}{c}\text { Energy } \\
\text { consump }\end{array}$ \\
Con $_{\mathrm{ephWW}}^{f a j}$ \\
\end{tabular}} & \multirow{2}{*}{\begin{tabular}{|c|c}
$\begin{array}{c}\text { Water } \\
\text { consump }\end{array}$ \\
Consagus \\
abb
\end{tabular}} & \multirow{2}{*}{\begin{tabular}{|c|}
$\begin{array}{c}\text { Non } \\
\text { Hazardous } \\
\text { waste }\end{array}$ \\
Gen ressmp \\
fab \\
\end{tabular}} & \multirow{2}{*}{\begin{tabular}{|c|}
$\begin{array}{c}\text { Hazardous } \\
\text { waste }\end{array}$ \\
$\sigma \in n_{q \varepsilon g s}^{f a b}$ \\
\end{tabular}} & \multirow{2}{*}{ 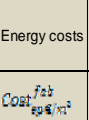 } & \multirow{2}{*}{\begin{tabular}{|c}
$\begin{array}{c}\text { Investment } \\
\text { costs }\end{array}$ \\
$\operatorname{Cost}_{\mathrm{q} / \mathrm{m}^{2}}^{\mathrm{fab}}$
\end{tabular}} & \multirow{2}{*}{\begin{tabular}{|l} 
Eq. $\mathrm{CO}_{2}$ \\
emissions
\end{tabular}} & \multirow{2}{*}{\begin{tabular}{|c}
$\begin{array}{c}\text { Energy } \\
\text { consump }\end{array}$ \\
Com $_{\mathrm{BphWh}}^{\text {man }}$
\end{tabular}} & \multirow{2}{*}{ 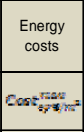 } & \multirow{2}{*}{\begin{tabular}{|l}
$\begin{array}{c}\text { Retrofit } \\
\text { costs }\end{array}$ \\
$\operatorname{Cost}_{\boldsymbol{i} / \mathrm{m}^{2}}$
\end{tabular}} \\
\hline & & & in & & - & & & & & & & & & & & & & \\
\hline & Type & Fs & $\mathrm{C}_{1} \mathrm{C}_{2} \mathrm{C} 3$ & 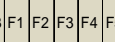 & $\mathrm{H} 1 \mathrm{H} 2 \mathrm{H} 3$ & NE SE & $\begin{array}{lll}\text { B3 } & \text { E1 }\end{array}$ & & & & & & & & & & & \\
\hline SEMIDET & $\infty$ & 0,72 & & & & & & \multirow{3}{*}{0,87} & \multirow{3}{*}{1,00} & \multirow{3}{*}{0,92} & \multirow{3}{*}{0,52} & \multirow{3}{*}{1,00} & \multirow{3}{*}{0,92} & \multirow{3}{*}{0,63} & \multirow{3}{*}{0,95} & \multirow{3}{*}{0,98} & \multirow{3}{*}{0,98} & \\
\hline BLOCK & 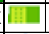 & 0,23 & & & & & & & & & & & & & & & & 0,52 \\
\hline DETACHED & $\infty$ & 1,00 & & & & & & & & & & & & & & & & \\
\hline SEMIDET & -1 & 0,72 & & & & & & & & & & & & & & & & \\
\hline BLOCK & 嘈楮 & 0,23 & & & & & & 0,89 & 1,00 & 0,59 & 0,73 & 1,00 & 0,94 & 0,79 & 0,96 & 0,98 & 0,98 & 0,69 \\
\hline DETACHED & $\infty$ & 1,00 & & & & & & & & & & & & & & & & \\
\hline SEMIDET & $\infty$ & 0,53 & & & & & & & & & & & & & & & & \\
\hline (1) BLOCK & intin & 0,63 & & & & & & 0,91 & 1,00 & 1,00 & 0,63 & 1,00 & 0,95 & 0,92 & 0,98 & 0,99 & 0,99 & 0,95 \\
\hline D DETACHED & $\infty$ & 1,44 & & & & & & & & & & & & & & & & \\
\hline SEMIDET & $\infty$ & 0,53 & & & & & & & & & & & & & & & & \\
\hline BLOCK & 面四 & 0,63 & & & & & & 0,93 & 1,00 & 0,94 & 0,81 & 1,00 & 0,96 & 1,00 & 0,98 & 0,99 & 0,99 & 1,00 \\
\hline DETACHED & $\infty$ & 1,44 & & & & & & & & & & & & & & & & \\
\hline - SEMIDET & 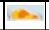 & 1,00 & & & & & & & & & & & & & & & & \\
\hline BLOCK & III & 1,44 & & & & & & 0,79 & 1,00 & 0,39 & 0,00 & 1,00 & 0,88 & 0,00 & 0,93 & 0,97 & 0,97 & 0,00 \\
\hline DETACHED & $\infty$ & 0,25 & & & & & & & & & & & & & & & & \\
\hline SEMIDET & 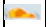 & 1,00 & & & & & & & & & & & & & & & & \\
\hline BLOCK & 冓 & 1,44 & & & & & & 0,82 & 1,00 & 0,00 & 0,47 & 1,00 & 0,90 & 0,25 & 0,94 & 0,97 & 0,97 & 0,23 \\
\hline C DETACHED & 4 & 0,25 & & & & & & & & & & & & & & & & \\
\hline
\end{tabular}

Table 14 Normalisation matrix: Result of the normalised values of each impact in the use phase of the life cycle 


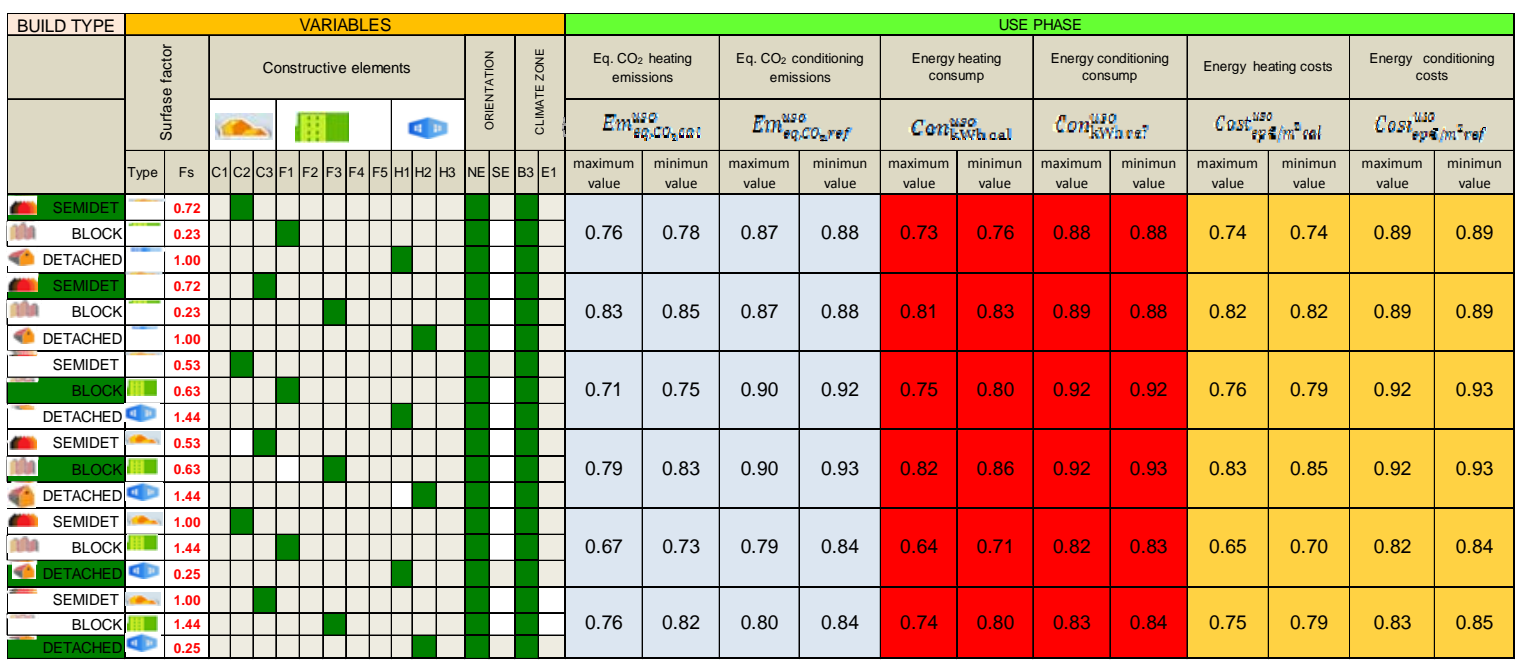

The last step of the model consists of providing a single overall score for each impact that has into account all the life cycle phases studied. The aggregation method requires a weighting process based on trade-offs between different environmental impacts, and hence it is considered the most subjective part of a LCA. Different weighting methods can give different and sometimes contradictory results [36]. Any aggregation method is considered subjective according to the ISO standards. In this model, the simple addition is selected because even if it as subjective as any other method, it offers as advantage in comparison to others the fact that it gives more freedom to the decision maker to do his own trade-offs, without biasing his/her choices towards a type of impact.

With the simple addition the score will go from 0 to 4 , where 0 is the worst possible value within the proposed scale and 4 is the maximum value that can be attained by an indicator. To obtain this overall score of the combination of building envelope assemblies that allows to compare each of the impact categories with each other, the values of each impact category are scaled up to a range of 0 to 4 . These values are obtained from the matrix of normalised values (Tables 3-14). This requires to consider the number of times that the impact appears in the normalised matrix. For example, $\mathrm{CO}_{2}$ emissions show up four times: the first one for the manufacturing phase, the second one for the maintenance phase, and the third and fourth times for the heating and cooling during the use phase respectively. Since each of these impacts has a value from 0 to 1 , to scale them up to the range of 0 to 4, they are summed up (equation [6]). For the energy consumption indicator the same calculation is taken (equation [7]). Water consumption is obtained exclusively for the manufacturing phase. For this reason to scale it up to a range of 0 to 4 , the impact is multiplied by four (equation [8]). Regarding waste generation, there are two normalised input, nonhazardous and hazardous waste, both of which are produced in the manufacturing phase. For this reason, they are summed up and the result is multiplied by two (equation [9]). Lastly, there are six different normalized values for the cost of the different phases. For this reason to scale this indicator value up to a 0 to 4 range, it is necessary to sum these six normalized values up and the result is divided by six and multiplied by four (equation [10]).

$$
\begin{aligned}
& \mathrm{Em}_{\text {eq } \mathrm{CO}_{2}}=\mathrm{Em}_{\text {eq } \mathrm{CO}_{2}}^{\mathrm{fab}}+\mathrm{Em}_{\text {eq CO}}^{\mathrm{man}}+\mathrm{Em}_{\text {eq } \mathrm{CO}_{2} \mathrm{cal}}^{\text {uso }}+\mathrm{Em}_{\text {eq } \mathrm{CO}_{2} \mathrm{ref}}^{\text {uso }} \\
& \operatorname{Con}_{e p k w h}=\operatorname{Con}_{e p k w h}^{f a b}+\operatorname{Con}_{e p k w h}^{\text {man }}+\operatorname{Con}_{k w h c a l}^{u s o}+\operatorname{Con}_{k w h r e f}^{u s o} \\
& \operatorname{Con}_{a g u a}=\operatorname{Con}_{a g u a}^{f a b} \cdot 4 \\
& G e n_{\text {res }}=\left(G e n_{\text {resnp }}^{f a b}+G e n_{\text {resp }}^{f a b}\right) \cdot 2 \\
& \operatorname{Cost}_{€ / m^{2}}=\left(\operatorname{Cost}_{e p € / m^{2}}^{f a b}+\operatorname{Cost}_{€ / m^{2}}^{f a b}+\operatorname{Cost}_{e p € / m^{2}}^{\operatorname{man}}+\operatorname{Cost}_{€ / m^{2}}^{\operatorname{man}}+\operatorname{Cost}_{e p € / m^{2} c a l}^{u s o}+\operatorname{Cost}_{e p € / m^{2} r e f}^{u s o}\right) \cdot \frac{4}{6}
\end{aligned}
$$

Weighting the indicators makes it possible to obtain a single value, ranging from 0 to 4 , for each of the five indicators considered globally in the whole life cycle. These results are represented on a new matrix that has been called the decision matrix because it allows different design options to be compared, thereby facilitating decision-making (Table 13). 
The indicators on the decision matrix refer to the whole life cycle of the building; the right-hand side of the decision matrix will therefore have only five columns of results, each column being identified by the name of the corresponding indicator.

\begin{tabular}{|c|c|c|c|c|c|c|c|c|c|c|c|c|c|c|c|c|c|c|c|}
\hline \multirow[t]{4}{*}{ BUILD TYPE } & \multicolumn{11}{|c|}{ VARIABLES } & \multicolumn{8}{|c|}{ FULL LIFE CYCLE } \\
\hline & \multirow{2}{*}{\multicolumn{2}{|c|}{ 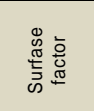 }} & \multicolumn{7}{|c|}{ Constructive elements } & \multirow{2}{*}{ 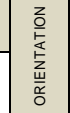 } & \multirow{2}{*}{ 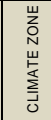 } & \multirow{2}{*}{\multicolumn{8}{|c|}{ WEIGHTED VALUE OF INDICATORS }} \\
\hline & & & \multicolumn{2}{|c|}{$\Leftrightarrow$} & \multicolumn{3}{|c|}{ 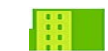 } & \multicolumn{2}{|r|}{ \& $\mathrm{B}$} & & & & & & & & & & \\
\hline & Type & Fs & $\mathrm{C} 1 \mathrm{C2}$ & C3 F & $\mathrm{F} 1 \mid \mathrm{F} 2$ & $2 \mathrm{F3}$ & F4 & F5 & \begin{tabular}{|l|ll}
$\mathrm{H} 1$ & $\mathrm{H} 2$ & $\mathrm{H} 3$ \\
\end{tabular} & NE SE & B3 E1 & \multicolumn{2}{|c|}{ Eq. $\mathrm{CO}_{2}$ emissions } & \multicolumn{2}{|c|}{ Energy consump } & $\begin{array}{l}\text { Water } \\
\text { consump }\end{array}$ & $\begin{array}{c}\text { Waste } \\
\text { Hazardous } \\
\text { and non } \\
\text { hazardous } \\
\end{array}$ & \multicolumn{2}{|c|}{$\begin{array}{l}\text { Energy investment } \\
\text { costs }\end{array}$} \\
\hline & & & & & & & & & & & & \multicolumn{2}{|c|}{ interval value } & \multicolumn{2}{|c|}{ interval value } & value & value & \multicolumn{2}{|c|}{ interval value } \\
\hline SEMIDET & $=-$ & 0.72 & & & & & & & & & & \multirow{3}{*}{3.45} & \multirow{3}{*}{3.48} & \multirow{3}{*}{3.59} & \multirow{3}{*}{3.61} & \multirow{3}{*}{3.68} & \multirow{3}{*}{3.03} & \multirow{3}{*}{3.13} & \multirow{3}{*}{3.13} \\
\hline BLOCK & 嘈䛛 & 0.23 & & & & & & & & & & & & & & & & & \\
\hline D. DETACHED & a & 1.00 & & & & & & & & & & & & & & & & & \\
\hline 리 SEMIDET & $\infty$ & 0.72 & & & & & & & & & & \multirow{3}{*}{3.55} & \multirow{3}{*}{2.62} & \multirow{3}{*}{3.68} & & & & & \\
\hline DII BLOCK & \begin{tabular}{|l|l|l}
1 \\
\end{tabular} & 0.23 & & & & & & & & & & & & & 3.69 & 2.35 & 3.46 & 2.32 & 2.32 \\
\hline - DETACHED & 4 & 1.00 & & & & & & & & & & & & & & & & & \\
\hline SEMIDET & $\infty$ & 0.53 & & & & & & & & & & & & & & & & & \\
\hline Dih BLOCK & III & 0.63 & & & & & & & & & & 3.51 & 2.58 & 3.64 & 3.71 & 4.00 & 3.26 & 2.39 & 2.42 \\
\hline ( DETACHED & 4 & 1.44 & & & & & & & & & & & & & & & & & \\
\hline SEMIDET & $-\infty$ & 0.53 & & & & & & & & & & & & & & & & & \\
\hline Dil BLOCK & 嘈四 & 0.63 & & & & & & & & & & 3.61 & 3.66 & 3.72 & 3.77 & 3.76 & 3.62 & 2.49 & 2.52 \\
\hline ○ DETACHED & $\Leftrightarrow$ & 1.44 & & & & & & & & & & & & & & & & & \\
\hline SEMIDET & $\infty$ & 1.00 & & & & & & & & & & & & & & & & & \\
\hline BII BLOCK & F嘈四 & 1.44 & & & & & & & & & & 2.25 & 2.36 & 3.42 & 3.50 & 1.56 & 2.00 & 1.63 & 1.67 \\
\hline 10 DETACHED & 40 & 0.25 & & & & & & & & & & & & & & & & & \\
\hline SEMIDET & $\infty$ & 1.00 & & & & & & & & & & & & & & & & & \\
\hline BLOCK & 嘈故 & 1.44 & & & & & & & & & & 2.38 & 2.48 & 3.54 & 3.60 & 0.00 & 2.94 & 1.87 & 1.90 \\
\hline 1. DETACHED & \& & 0.25 & & & & & & & & & & & & & & & & & \\
\hline
\end{tabular}

In order to assess the importance of the obtained results with respect to other reference data, they are compared to the emissions associated to an average dwelling in Spain, estimated in $2.992 \mathrm{~kg} \mathrm{CO}_{2}$ [36]. For example, the difference in $\mathrm{CO} 2$ emissions between the combination $\mathrm{C} 2 \mathrm{~F} 1 \mathrm{H} 1$ (ventilated flat roof, brick cavity wall with external wall coating and $5 \mathrm{~cm}$ insulation, and aluminium carpentry) and the combination C3F3H2 (inverted flat roof, brick cavity wall with external wall coating and $10 \mathrm{~cm}$ insulation, and PVC carpentry), in a lifetime of 50 years for the semi-detached house is of $179.91 \mathrm{~kg} \mathrm{CO} 2 / \mathrm{m}^{2}$. This represents 23.94\% less emissions for the first option per square meter of net floor. The difference between choosing one combination over another one is in total $16,761.63 \mathrm{~kg} \mathrm{CO}_{2}$ in 50 years; that is to say, the selection of one combination over another one may represent emissions savings equivalent to the overall emissions of an average dwelling in Spain during 5.6 years.

\section{Conclusions}

A model has been developed to calculate the environmental impacts related to the materials used during the manufacturing, installation and maintenance phases of the envelope of residential buildings (embodied impacts), as well as the impacts generated by the heating and cooling installations due to the contribution of the envelope to energy efficiency during the use phase of the building (operating impacts). It also makes it possible to evaluate the economic cost of the impacts associated to its life cycle in terms of both investment and energy saving.

The developed model allows to obtain and compare live estimated data about the environmental embodied and operational impacts of different building envelope assemblies at the early phases of materials selection. The calculation matrix allows the planner to know the value of the estimated impacts of each of the possible combinations by selecting different options on the matrix.

The normalisation matrix provides the planner with a normalised value for each impact in the different phases of the life cycle. The results obtained in this matrix are dimensionless values between 0 and 1 that are easily comparable. The colour coding makes it easier to identify the indicators. Simplifying the homogenised values allows the planner to compare the weight of a particular impact in the different phases of the life cycle or to compare the weight of a specific impact in different building assemblies. Likewise, the planner can compare the investment costs with the costs of the energy consumed at the end of the life cycle and also obtain the saving that can be obtained by choosing one particular combination rather than another, in terms of both investment and energy saving. 
The decision matrix makes it possible to estimate an overall score per indicator and even an overall score for the environmental behaviour of each combination of building envelope assemblies that is evaluated; this value can be used in the catalogues of building assemblies covering a range from 0 to 4 . The score obtained can be used, if a limit is established, to require that a minimum value is reached in order to be able to use a particular combination in a climate zone or in an orientation.

It has been found that the model developed here can be applied to three types of residential use: a semidetached house, a block of apartments and a standalone detached house. Hence, the designer planner can know the estimated value of the impacts of different alternative envelopes in these three different types of building in the different phases of the life cycle.

As a final conclusion, it could be said that the model developed here can make the planner's job easier by characterising, comparing and selecting alternatives not only in terms of materials but also at an intermediate level between the material and the building, by combining different materials that go to make up the building assembly. It provides a scale of comparison that allows the impacts of all the phases of the life cycle of the building to be related, as well as allowing easy detection of the most critical phase or the most critical impact.

It offers a system of scoring based on indicators that can be integrated within construction databases and catalogues of building assemblies, including economic-environmental criteria.

This work has limitations regarding the uncertainty of the estimations that the model can produce because it relies on data from energy simulation tools, instead of from real building data. Within the building industry, there is an increasing concern about the mismatch between the predicted performance of buildings energy behaviour and the actual measured performance. Studying this gap was beyond the scope of the present paper. However, it is a line of research currently being studied by the scientific community. In this paper, for the moment we have just provided a level of uncertainty associated to the process of obtaining the equations by means of simulation models. In the future, when the gap between predicted performance of buildings energy and real building energy behaviour is better diagnosed, the level of uncertainty will require to be updated with regard to real data.

\section{Acknowledgements}

The authors gratefully acknowledge financial support from the Ministry of Economy and Competitiveness, Project BIA2013-44001-R: Integrated design protocol for social housing retrofit and urban regeneration.

\section{References}

[1] Oteiza I, Alonso C. Análisis y revisión de herramientas para evaluación de la sostenibilidad de la construcción. Actas de las II Jornadas de Investigación en Construcción. Madrid, May 2008: 1149-1166.

[2] Casado Martínez N. Edificios de alta calidad ambiental. Ibérica, Alta Tecnología ISSN 0211-0776. 1996

[3] López-Mesa B, Gallego T, Mulet E, Pitarch A, Tomás A. Exploring the need for an evaluation model to assist in the eco-efficient selection of building systems. Proceedings of the 16th International Conference on Engineering Design (ICED). Paris. 2007.

[4] Ruá MJ. "Métodos de valoración de viviendas desde la perspectiva medioambiental y análisis de costes", Ph. D. thesis, Universidad Politécnica de Valencia, Valencia, Spain. July 1, 2011.

[5] Haapio A, Viitaniemi P. A critical review of building environmental assessment tools. Environmental Impact Assessment Review 2008; Vol. 28 No. 7: 469-482.

[6] Huedo P, López-Mesa B. Review of tools to assist in the selection of sustainable building assemblies. Informes de la Construcción 2012; IC-11-048: 0020-0883. 
[7] Zabalza I, Aranda A, Scarpellini S. Life cycle assessment in buildings: State-of-the-art and simplified LCA methodology as a complement for building certification. Building and Environment 2009; 44: 2510 2520.

[8] Mateus, R., Bragança, L., Sustainable assessment and rating of buildings: Developing the methology SBtoolpt -H. Building and Environment 46. 1962-1971 (2011).

[9] Rúa MJ, López-Mesa B, Vives L, Civera V. Environmental advantage of back-ventilated façades in comparison with brick cavity walls in residential buildings, In: Morena J, Acosta, eds., Advances in Energy Research 2012; Vol 8: 315-352. New York: Nova Sciences Publishers. ISBN 978-1-61324-2.

[10] Alonso C, Oteiza I, García J. Criterios para la reducción de emisiones de gases de efecto invernadero en el proyecto de fachadas de edificios de Viviendas. II Congreso Nacional Investigación en Edificación. ISBN: 978-84-2844-693-8. Madrid 2010.

[11] Mithraratne, N. y Vale, B.(2004) "Life cycle analysis model for New Zealand houses", Building and Environment, vol. 39, pp. 483-492, Apr 2004. School of Architecture, The University of Auckland, Private Bag 92019, Auckland, New Zealand 2004

[12] Alías, H., Jacobo, G. (2008) “Construcción sostenible. Materiales de construcción energética y ambientalmente eficientes en el nordeste de Argentina”. Ciudades para un futuro más sostenible. Boletín CF+S 35. Instituto Juan de Herrera. Madrid ISSN: 1578-097X. Marzo 2008.

[13] T. Argüello and A. Cuchí, "Analysis of the environmental impact associated with the materials of construction used in the low cost houses of the program 10 x10 With Roof-Chiapas of the CYTED", Informes de la Construcción, vol. 60, pp. 25-34, January-March 2008.

[14] Verbeeck, G., Hens, H. (2009) Life cycle inventory of buildings: A calculation method. Building and Environment 45(4): 1037-1041.

[15] Ortiz, O., Bonnet, C., Bruno J., Castells, F. (2010) "Sustainability based on LCM of residential dwellings: A case study in Catalonia, Spain”. Building and Environment 44: 584-594);

[16] Ruá, M.J., Vives, L., Civera, V., Lopez-Mesa, B. “Aproximación al cálculo de la eficiencia energética de fachadas ventiladas y su impacto ambiental". Actas del XI Congreso mundial de la calidad del azulejo y del pavimento cerámico QUALICER 2010, Castellón, 15-16 de febrero de 2010.

[17] MIMAM (2000). “Indicadores Ambientales. Una propuesta para España”. Dirección General de Calidad y Evaluación Ambiental. Ministerio de Medio Ambiente. 2000. MIMAM (2000). Centro de Publicaciones del Ministerio de Medio Ambiente. Madrid,

[18] OECD The Organisation for Economic Co-operation and Development. Cities for the 21st Century 1994. http://www.oecd.org/

[19] Casanovas X. Ponencia marco Sostenibilidad y medio ambiente. Barcelona 2009.

[20] Wadel R, Winograd M, Fernández N, Farrow A. Herramientas para la toma de decisiones en América Latina y el Caribe: indicadores ambientales y geográficos. Sistemas de Información. Centro Internacional de Agricultura Tropical (CIAT) y Programa de las Naciones, Unidas Para el Medio Ambiente (PNUMA), Cali, Colombia 1098.

[21] Martí X. Desarrollo Sostenible. Conclusiones del VI Congreso Nacional de Medio Ambiente (CONAMA). ISBN: 84-87338-10-0, Madrid 2003

[22] Garrido L. Un nuevo paradigma en arquitectura 2012. ISBN 978-84-15223-75-7. Editorial Monsa

[23] Huedo P. La evaluación del impacto ambiental de la envolvente del edificio como herramienta de apoyo en fase de diseño aplicada a viviendas. PhD thesis. Universitat Jaume I. Castellón 2014 
[24] EEA EMEP/CORINAIR Emission Inventory Guidebook 2007; Copenhagen, European Environment Agency.

[25] Mercader MP, Ramírez de Arellano A. Selective classification and quantification model of C\&D waste from material resources consumed in residential building construction. Waste Management \& Research 2013; Vol. 31. Núm. 5: 458-474.

[26] Ramírez de Arellano, Llatas-Oliver AC, García-Torres I, Linares-Romero P, García-Caraballo EI, Escobar M, Carnerero M, Hernández R. Retirada Selectiva de Residuos: Modelo de Presupuestación. p.5, Fundación Aparejadores. Sevilla, 2002

[27] Enslic Building. Guidelines for LCA Calculations in early design phases Energy Saving through Promotion of Life Cycle Assessment. EIE/07/090/SI2.467609 in (2010)

[28] TCQ2000 y su módulo TCQGMA - Módulo de gestión ambiental. ITeC - Programa para los proyectos y obras de construcción - TCQ, ITeC (Instituto de la Construcción de Cataluña), Barcelona, [Online] Available; http://itec.es/programas/tcq/.

[29] BEDEC, database of construction materials developed by ITeC (Instituto de la Construcción de Catalunya), Barcelona, 2013 version, [Online] Available; http://itec.es/nouBedec.e/.

[30] Nemry F, Uihlein A, Makishi C, Wittstock B, Braune A. Environmental Improvement Potentials of Residential Buildings (IMPRO-Building). EUR 23493 EN, ISBN 978-92-79-09767-6. Office for Official Publications of the European Communities, 2008. [E-book] Luxembourg 2008.

[31] Hernández Moreno, Silverio et al. (2011) "Aplicación de la información de la vida útil en la planeación y diseño de proyectos de edificación”. Acta Universitaria, vol. 21, núm. 2, mayo-agosto, 2011, pp. 37-42. Universidad de Guanajuato. México

[32] L. Ortega, "Propuesta metodológica para estimar la vida útil de los sistemas constructivos de fachadas y cubiertas utilizados actualmente con más frecuencia en la edificación española a partir del método propuesto por la Norma ISO-15686”, Ph. D. thesis, Universitat Politécnica de Valencia, Valencia. December, 2012.

[33] LIDER v1.0. Manual de usuario, Instituto para la Diversificación y Ahorro de la Energía (IDAE) y Dirección General de Arquitectura y Política de Vivienda, 2007. [Online] Available; http://www.codigotecnico.org/web/galerias/archivos/ManualLIDER.pdf

[34] CALENER VYP Software from the Ministerio de Vivienda, IDAE.

[35] CTE WEB (http://cte-web.iccl.es/sistemas.php?t=6\&p=2) 2009

[36] Finnveden, G.,1996,Valuation Methods within the Framework of Life Cycle Assessment. Swedish Environmental Research Institute, Stockholm.

[37] Hernández-Sánchez, J.M. "Consumo energético y emisiones asociadas del sector residencial". International Congress on Project Engineering. "15th International Congress on Project Engineering". Huesca: Asociación Española de Ingeniería de Proyectos, 2012. 